\title{
ALBERTA ENVIRONMENT SUMMARY REPORT ON 2005 GREENHOUSE GAS EMISSIONS
}
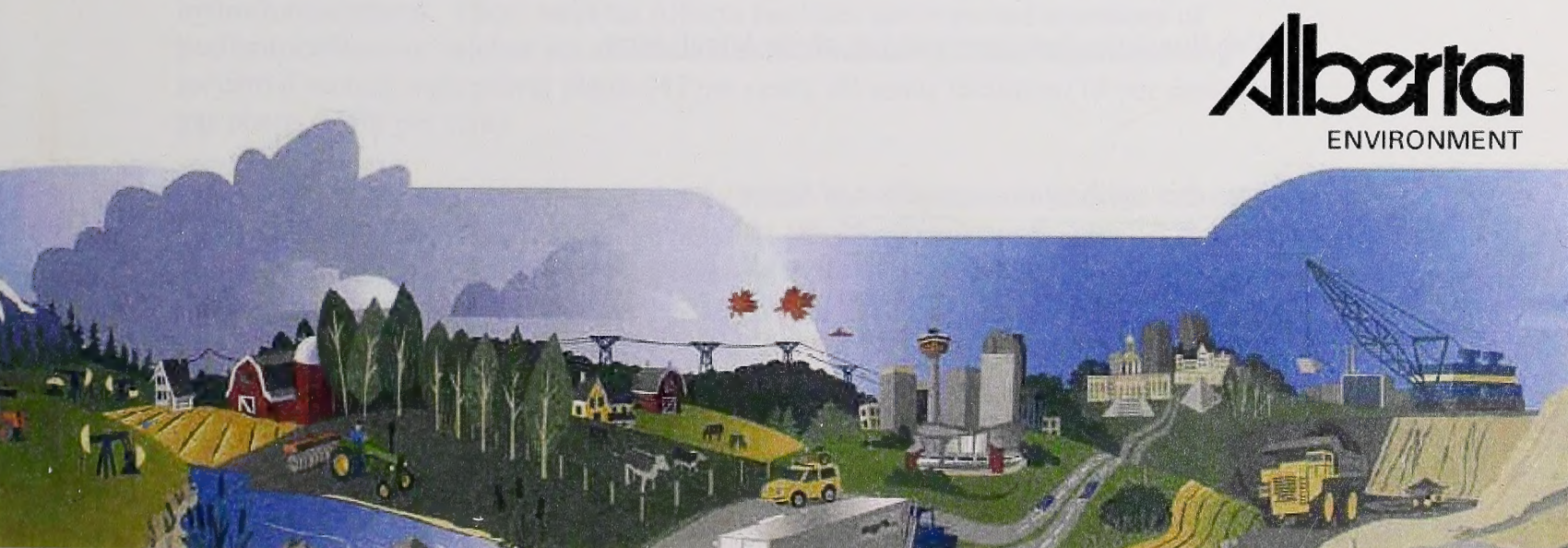


\section{Disclaimer:}

The information contained in this report has been obtained from several different sources. Effort has been made to ensure its validity, but the authors cannot guarantee the correctness of data.

Decisions based on the contents of this report are solely at the discretion of the reader. The 2004 and 2005 greenhouse gas data collected under the Specified Gas Reporting Program is current as of November 30, 2006. Emissions values have been rounded to protect confidential information.

Prepared by:

Evaluation and Reporting Section

Environmental Monitoring and Evaluation Branch

Environmental Assurance

Alberta Environment

12th floor, Oxbridge Place

9820 - 106th Street

Edmonton, AB

T5K 2J6

Phone: (780) 427-0685

Fax: (780) 422-8606

Additional copies of this document may be obtained by contacting:

Alberta Environment Information Centre

Main Floor, 9820 - 106 Street

Edmonton, Alberta T5K 2L6

Phone: (780) 427-2700 (Toll free by first dialing 310-000)

Fax: (780) 422-4086

E-mail: env.infocent@gov.ab.ca

ISBN: 978-0-7785-5466-0 (Printed)

ISBN: 978-0-7785-5467-7 (On-line)

Web Site: http://environment.gov.ab.ca/default.aspx

Copyright in this publication, regardless of format, belongs to Her Majesty the Queen in right of the Province of Alberta. Reproduction of this publication, in whole or in part, regardless of purpose, requires the prior written permission of Alberta Environment.

Her Majesty the Queen in right of the Province of Alberta, 2007. 


\section{Executive summary}

The Government of Alberta is committed to taking action on climate change. Beginning with its Climate Change Action Plan - Albertans \& Climate Change: Taking Action, released in October 2002, the Government of Alberta identified a number of strategies the province would use to address climate change. One of these actions included the development of a mandatory reporting program for large industrial emitters in Alberta.

Beginning in November 2004, large industrial emitters in the province were required to submit an annual report on their previous year's greenhouse gas emissions. The Specified Gas Reporting Program requires any Alberta industrial facility that emits more than 100 kilotonnes $(\mathrm{kt})$ of greenhouse gases, expressed as carbon dioxide equivalent, to report their emissions to Alberta Environment through a secure electronic data reporting system. Beginning with 2004 reporting, the Alberta system was harmonized with the National Mandatory Greenhouse Gas Reporting Program.

\section{Alberta in 2005}

Alberta's growing economy presents unique challenges for addressing greenhouse gas emissions and climate change. Our province has specialized resource-based industries that are less prevalent in other parts of Canada. We are also experiencing strong economic growth, which is usually accompanied by increased greenhouse gas emissions.

For the 2005 reporting year, 101 Alberta facilities reported total greenhouse gas emissions of 109 megatonnes (Mt). This represents an increase of three facilities reporting compared to the 2004 reporting year, with emissions remaining nearly unchanged (a decrease of $0.1 \mathrm{Mt}$ ).

Alberta facilities accounted for 39 per cent of the 2005 total Canadian reported greenhouse emissions, captured under the National Mandatory Greenhouse Gas Reporting Program. Alberta facilities were the source of 40 per cent of emissions of carbon dioxide, 43 per cent of emissions of methane, 26 per cent of emissions of nitrous oxide and 15 per cent of emissions of hydrofluorocarbons.

Ninety-five per cent of the total reported Alberta greenhouse gas emissions were in the form of carbon dioxide. The remainder was in the form of methane, nitrous oxide and hydrofluorocarbons. There were no Alberta facilities that reported emissions of perfluorocarbons or sulphur hexafluoride for 2005 reporting. The largest emitting industrial sectors were power plants (47 per cent), oil sands facilities ( 19 per cent) and gas plants (eight per cent).

Ninety-four Alberta facilities reported greenhouse gas emissions in both the 2004 and 2005 reporting years. The net change in emissions for these 94 facilities was a decrease of 0.3 megatonnes. It is unclear if the changes in emissions between reporting years are due to refinements in calculation methods or absolute changes in emissions. 
The reporting system allows specified gas reporters to request that portions of their report be kept confidential, for a period of up to five years, on the basis that the information is commercial, financial, scientific or technical detail that would reveal proprietary business, competitive or trade secret information about a specific facility, technology or corporate initiative. Seven Alberta facilities requested confidentiality for their reported greenhouse gas information; a significant decrease as compared to past reporting years. All seven of these facilities were granted confidentiality for emissions by source category and one facility was also granted confidentiality for gas totals.

\section{Key findings (2004 National Greenhouse Gas Inventory)}

The National Mandatory Greenhouse Gas Reporting Program just covers industrial sources, whereas the National Greenhouse Gas Inventory includes estimates of emissions from other sources including transportation, agriculture, construction, commercial, institutional and residential. The 2004 National Greenhouse Gas Inventory estimated there was a total of 235 megatonnes of greenhouse gases emitted from all sources in Alberta. Seventy-eight per cent of these emissions were carbon dioxide, 17 per cent were methane and five per cent were nitrous oxide.

Six sources were responsible for almost 90 per cent of 2004 Alberta greenhouse gas emissions. These sources were fossil fuel industries ( 37 per cent), electricity and heat generation (22 per cent), transportation (13 per cent), agriculture (seven per cent), industrial processes (six per cent) and mining (five per cent). Combining all industrial sources into a single category showed that industrial sources were responsible for 73 per cent of total greenhouse gas emissions in Alberta.

Based on comparisons to the National Greenhouse Gas Inventory, the current industry reporting program captures 47 per cent of total greenhouse gas in Alberta. The reporting program captures 57 per cent of carbon dioxide, nine per cent of methane and 15 per cent of nitrous oxide emissions in the province.

Total absolute Alberta greenhouse gas emissions from all sources have increased by 40 per cent since 1990, while emissions intensity (kilotonnes of greenhouse gas emissions per million dollars GDP) decreased by 16 per cent over the same period. Alberta is therefore more than one quarter of the way to meeting its target of reducing emissions intensity by 50 per cent below 1990 levels by 2020. Furthermore, Alberta is over half way to meeting its interim 2010 target of a 30 per cent reduction in greenhouse gas emissions intensity.

\section{Future activities on climate change}

Alberta is planning future amendments to the Climate Change and Emissions Management Act including development of regulations to establish emissions intensity reduction targets for industrial facilities. The amendments and regulations reaffirm Alberta's commitment to manage greenhouse gases and together outline the Alberta regulatory approach to managing emissions from large industrial facilities. 


\section{Table of contents}

Executive summary................................................................................................................ii

Table of contents .................................................................................................................. v

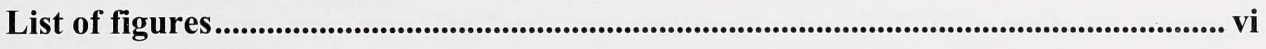

List of tables........................................................................................................................... vi

1.0 Alberta taking action on climate change ....................................................................... 1

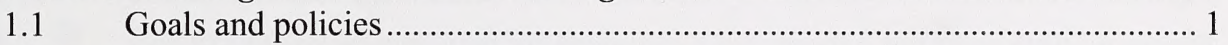

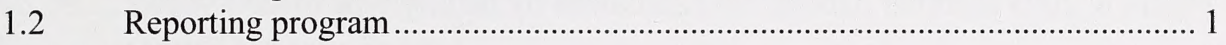

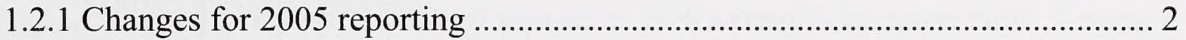

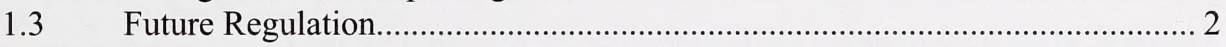

1.3.1 Climate Change and Emissions Management Act........................................... 2

1.3.2 Specified Gas Emitters Regulation .............................................................. 2

2.0 Confidentiality.............................................................................................................. 4

$2.1 \quad$ Confidentiality request process .................................................................. 4

2.2 Confidentiality requests and decisions........................................................ 4

3.02005 reported emissions ................................................................................................. 5

3.1 Total reported GHG emissions .............................................................. 5

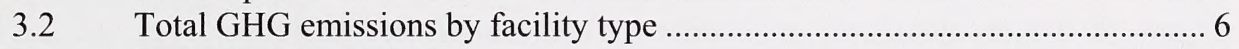

3.3 Emissions by GHG Gas type …………………...................................... 7

3.3.1 Carbon dioxide emissions ........................................................................ 7

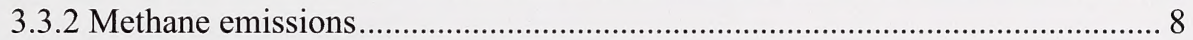

3.3.3 Nitrous oxide emissions ......................................................................... 9

3.3.4 Emissions of hydrofluorocarbons …………………….................................. 10

3.4 Reported emissions by facility type and GHG gas type ................................. 10

4.0 Comparison of 2005 to 2004 GHG emissions ........................................................... 12

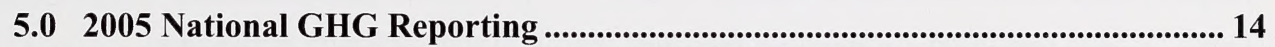

5.12005 reported GHG emissions by province.................................................. 14

5.1.1 Reported carbon dioxide emissions by province …………………………..... 14

5.1.2 Reported methane emissions by province......................................................... 15

5.1.3 Reported nitrous oxide emissions by province ................................................. 16

5.1.4 Reported emissions of hydrofluorocarbons by province ................................. 17

6.0 Comparison to national inventory (2004) ................................................................ 19

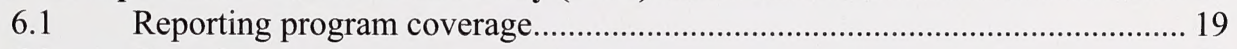

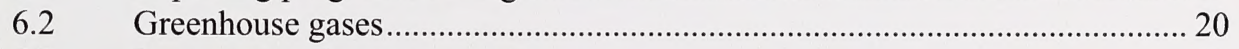

6.3 Largest greenhouse gas sources ................................................................... 21

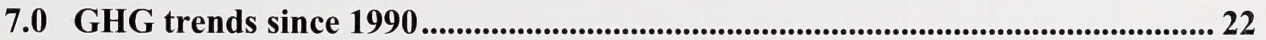

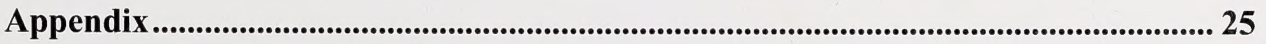

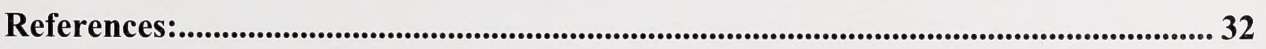




\section{List of figures}

Figure 1: 2005 reported Alberta GHG emissions by gas............................................ 5

Figure 2: 2005 reported Alberta GHG emissions by facility type............................... 6

Figure 3: Number of 2005 Alberta facilities reporting GHG emissions by facility type. .. 7

Figure 4: 2005 reported Alberta $\mathrm{CO}_{2}$ emissions by facility type.................................. 8

Figure 5: 2005 reported Alberta $\mathrm{CH}_{4}$ emissions by facility type................................ 9

Figure 6: 2005 reported Alberta $\mathrm{N}_{2} \mathrm{O}$ emissions by facility type in kt. ...................... 10

Figure 7: 2005 reported Alberta GHG emissions by facility type and gas.................... 11

Figure 8: 2005 total reported GHG emissions by province/territory........................... 14

Figure 9: 2005 total reported $\mathrm{CO}_{2}$ emissions by province/territory.......................... 15

Figure 10: 2005 total reported $\mathrm{CH}_{4}$ emissions by province/territory........................... 16

Figure 11: 2005 total reported $\mathrm{N}_{2} \mathrm{O}$ emissions by province/territory. .......................... 17

Figure 12: 2005 total reported HFC emissions by province/territory in kt..................... 18

Figure 13: 2004 Alberta GHG emissions from all sources (National Inventory)........... 20

Figure 14: Trends in Alberta greenhouse gas emissions (National Inventory). ............. 23

Figure 15: Alberta GHG emissions intensity (1997 Dollars). ................................... 23

\section{List of tables}

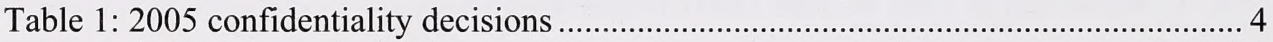

Table 2: 2004 and 2005 comparable facilities seeing higher or lower emissions. .......... 13

Table 3: Total 2005 reported greenhouse gas emissions by facility type...................... 26 


\section{Abbreviations}

AENV: Alberta Environment

AB: Alberta

BC: $\quad$ British Columbia

$\mathrm{CH}_{4}$ : methane

$\mathrm{CO}_{2}$ : carbon dioxide

$\mathrm{CO}_{2}$-e: $\quad$ carbon dioxide equivalent

EDR: $\quad$ Electronic Data Reporting System

GDP: Gross Domestic Product

HFCs: hydrofluorocarbons

kt: kilotonne

MN: Manitoba

Mt: megatonne

$\mathrm{N}_{2} \mathrm{O}$ : nitrous oxide

NB : $\quad$ New Brunswick

NL : $\quad$ Newfoundland \& Labrador

NS : Nova Scotia

NT : Northwest Territories

ON : Ontario

PE : $\quad$ Prince Edward Island

PFCs: perfluorocarbons

QC: Quebec

$\mathrm{SF}_{6}$ : $\quad$ sulphur hexafluoride

SK : Saskatchewan 


\subsection{Alberta taking action on climate change}

\subsection{Goals and policies}

The Government of Alberta is committed to reducing greenhouse gas emissions and developing an effective approach to responding to the potential risks of climate change. Alberta's plans are outlined in Albertans \& Climate Change: Taking Action ${ }^{i}$. The plan provides a comprehensive framework to reduce greenhouse gas emissions while maintaining a prosperous economy over the long term. By 2020, Alberta will cut greenhouse gas emissions in the province relative to Gross Domestic Product (GDP) by 50 per cent of 1990 levels. This should be approximately a 60 Megatonne (Mt) reduction in greenhouse gas emissions below expected business-as-usual levels. By 2010, it is estimated that Alberta will have achieved an emissions intensity improvement of roughly $20 \mathrm{Mt}$ below business-as-usual levels. Improvements in emissions intensities will improve the efficiency of facility operations, which in turn will increase the competitiveness of Alberta industries. The Government of Alberta continues to encourage the use of best practices and technologies.

There are three main components of the Specified Gas Reporting Program ${ }^{i i}$ - the Specified Gas Reporting Standard ${ }^{i i}$, the Specified Gas Reporting Regulation ${ }^{i v}$, and the Climate Change and Emissions Management Act ${ }^{v}$. Alberta's Climate Change Action Plan identifies the provincial Specified Gas Reporting Program as an important aspect of managing climate change. Information gathered under the program is needed to assist both the province and industry in characterizing emission sources and identifying opportunities for emission reductions. The program will allow the Government of Alberta to monitor progress of specific Alberta emission reduction strategies, such as setting greenhouse gas emission targets, establishing emission-trading systems, implementing greenhouse gas emissions reduction technologies for industry and promoting reductions in emissions intensity.

\subsection{Reporting program}

The Alberta Specified Gas Reporting Program ${ }^{i i}$ requires that all large Alberta industrial facilities emitting more than 100 kilotonnes $(\mathrm{kt})$ of greenhouse gases in carbon dioxide equivalent $\left(\mathrm{CO}_{2}-\mathrm{e}\right)$ units per year (based on the sum of direct emissions of carbon dioxide $\left(\mathrm{CO}_{2}\right)$, methane $\left(\mathrm{CH}_{4}\right)$ and nitrous oxide $\left(\mathrm{N}_{2} \mathrm{O}\right)$, hydrofluorocarbons (HFC), perflurorocarbons (PFC) and sulphur hexafluoride $\left.\left(\mathrm{SF}_{6}\right)\right)$ report their greenhouse gas emissions to Alberta Environment. Facilities are required to use an Electronic Data Reporting (EDR) system to submit their greenhouse gas reports, which is administered by Statistics Canada.

Alberta harmonized its Specified Gas Reporting Program with the National Mandatory Greenhouse Gas Reporting Program ${ }^{\underline{v} i}$ beginning with 2004 greenhouse gas reporting. The result is that facilities are required to report only once through the EDR to satisfy both provincial and federal reporting requirements. The Alberta data collected using the 
EDR is provided to both Alberta Environment and Environment Canada. Alberta facilities are required to submit separate Statements of Certification and requests for confidentiality directly to both Environment Canada and Alberta Environment via mail or courier.

The complete reporting requirements for 2005 reporting are outlined in the March 2006 version of the Specified Gas Reporting Standard ${ }^{i i i}$. The Alberta Specified Gas Reporting Program will continue to evolve in future years to gather the necessary emissions data for regulatory, industrial and public purposes.

\subsubsection{Changes for 2005 reporting}

One of the key changes to the Specified Gas Reporting Program ${ }^{i i}$ included replacement of the "other emissions" source category with the "on-site transportation emissions" and "waste and wastewater emissions" source categories. The "fugitive emission" source category was also replaced with the more specific "venting and flaring emissions" and "other fugitive emissions" source categories.

The reporting requirement for hydrofluorocarbons (HFC), perfluorocarbons (PFC) and sulphur hexafluoride $\left(\mathrm{SF}_{6}\right)$ were revised to include only those emissions of these gases from industrial process or industrial product use. In addition, this change was also made for calculating whether a facility exceeded the reporting threshold (HFC, $\mathrm{PFC}$ and $\mathrm{SF}_{6}$ only).

\subsection{Future Regulation}

Alberta is planning future amendments to the Climate Change and Emissions Management Act ${ }^{\nu}$ that will include regulations to establish emissions intensity reduction targets for industrial facilities. These steps will reaffirm Alberta's commitment to manage greenhouse gases and outline the Alberta regulatory approach to managing emissions from large industrial facilities.

\subsubsection{Climate Change and Emissions Management Act}

The Climate Change and Emissions Management Act is Alberta's primary legislation for regulating greenhouse gas emissions in the province. The act provides the regulatory framework necessary for setting provincial, sectoral and/or facility level targets, reporting as well as compliance and enforcement requirements. The act was passed in 2003 but was not proclaimed. Sections of the act were proclaimed when the Specified Gas Reporting Regulation ${ }^{i v}$ was passed in 2004 . Amendments to the act and proclamation of the remaining elements are necessary to provide the appropriate legislative authority for the implementation of the new greenhouse gas regulations.

\subsubsection{Specified Gas Emitters Regulation}

The Specified Gas Emitters Regulation is a new strategic regulation that will confirm Alberta's intent to set greenhouse gas intensity limits for large emitters of greenhouse 
gases in Alberta. The regulation represents the next important step in delivering on the current Climate Change Action Plan ${ }^{i}$ and addressing new emissions from a growing economy. It is based on the Government of Alberta's commitment to drive prudent emission intensity reductions in the short-term and encourages investment in technological change to support longer-term economic and environmental objectives.

The proposed amendments and regulations have been developed with significant input from industry and other stakeholders. The intent is to have both in place in time for the 2008 greenhouse gas emissions reporting year. 


\subsection{Confidentiality}

\subsection{Confidentiality request process}

The confidentiality provisions for the Specified Gas Reporting Program ${ }^{i i}$ are set out in section 5 of the Specified Gas Reporting Regulation ${ }^{i v}$, AR 251/2004. This section permits facilities that report greenhouse gas emissions to Alberta Environment to request confidentiality for some or all of their submitted data. The request must be based on the criteria set out in section 5 (1) and (2) of the regulation. The Director under the act has 90 days to reach a decision and can grant parts or the entire request, which results in information being held as confidential for up to five years.

\subsection{Confidentiality requests and decisions}

For the 2005 reporting year seven Alberta facilities requested and were granted confidentiality. The number of facilities requesting confidentiality for the submitted greenhouse gas data declined significantly from the two previous reporting years. For the 2003 reporting year 20 facilities requested confidentiality and for the 2004 reporting year 21 submitted requests for confidentiality. In 2004 nine facilities were granted some form of data confidentiality, of which seven submitted a confidentiality request for the 2005 reporting year.

Six of the seven confidentiality requests asked for detailed source-level greenhouse gas emissions data to be kept confidential and one request asked for detailed source-level and one request asked for detailed source-level and gas total greenhouse gas emissions be kept confidential. Table 1 provides the decisions on the 2005 confidentiality requests. All seven of the facilities that requested confidentiality for 2005 specified gas reporting were granted their requests for a period of five years, starting from the June 1, 2006 reporting deadline.

Table 1: 2005 confidentiality decisions

\begin{tabular}{|l|l|l|}
\hline Company Name: & Facility Name: & Decision: \\
\hline Imperial Oil & Cold Lake & $\begin{array}{l}\text { Section III (A) deemed confidential } \\
\text { for 5 years. }\end{array}$ \\
\hline Petro-Canada & Edmonton Refinery & $\begin{array}{l}\text { Section III (A) deemed confidential } \\
\text { for 5 years. }\end{array}$ \\
\hline Graymont & Exshaw & $\begin{array}{l}\text { Section III (A and C) deemed } \\
\text { confidential for 5 years. }\end{array}$ \\
\hline Albian Sands Energy Inc. & Muskeg River Mine & $\begin{array}{l}\text { Section III (A) deemed confidential } \\
\text { for 5 years. }\end{array}$ \\
\hline Shell Canada Limited & Scotford Refinery & $\begin{array}{l}\text { Section III (A) deemed confidential } \\
\text { for 5 years. }\end{array}$ \\
\hline Shell Canada Limited & $\begin{array}{l}\text { Scotford Upgrader and } \\
\text { Upgrader Cogeneration }\end{array}$ & $\begin{array}{l}\text { Section III (A) deemed confidential } \\
\text { for 5 years. }\end{array}$ \\
\hline Imperial Oil & Strathcona Refinery & $\begin{array}{l}\text { Section III (A) deemed confidential } \\
\text { for 5 years. }\end{array}$ \\
\hline
\end{tabular}




\subsection{5 reported emissions}

Note: All emissions numbers reported in this document are in carbon dioxide equivalent units.

\subsection{Total reported GHG emissions}

Total reported greenhouse gas emissions is the sum of emissions of carbon dioxide $\left(\mathrm{CO}_{2}\right)$, methane $\left(\mathrm{CH}_{4}\right)$, nitrous oxide $\left(\mathrm{N}_{2} \mathrm{O}\right)$, species of hydrofluorocarbons (HFC), species of perfluorocarbons $(\mathrm{PFC})$ and sulphur hexafluride $\left(\mathrm{SF}_{6}\right)$ all converted to carbon dioxide equivalent units using the global warming potentials specified in the Specified Gas Reporting Standard ${ }^{i i i}$. There were 101 Alberta facilities that submitted specified gas reports to Alberta Environment for the 2005 reporting year. Table 3 in the appendix provides the gas totals for the Alberta facilities for the 2005 reporting year, organized by facility type. Total reported greenhouse gas emissions were 109 megatonnes (Mt). Figure 1 shows the total reported emissions by greenhouse gas. Carbon dioxide made up 95 per cent of the total reported Alberta greenhouse gas emissions, or $104 \mathrm{Mt}$. Three per cent, or four $\mathrm{Mt}$, of the total reported greenhouse gas emissions were in the form of methane $\left(\mathrm{CH}_{4}\right)$ and two per cent, or two $\mathrm{Mt}$, of total reported greenhouse gas emissions were in the form of nitrous oxide $\left(\mathrm{N}_{2} \mathrm{O}\right)$. Eight kilotonnes $(\mathrm{kt})$ of greenhouse gases were emitted as hydrofluorocarbons (HFC). None of the Alberta facilities reported emissions of perfluorocarbons $(\mathrm{PFC})$ or sulphur hexafluride $\left(\mathrm{SF}_{6}\right)$ for the 2005 reporting year.

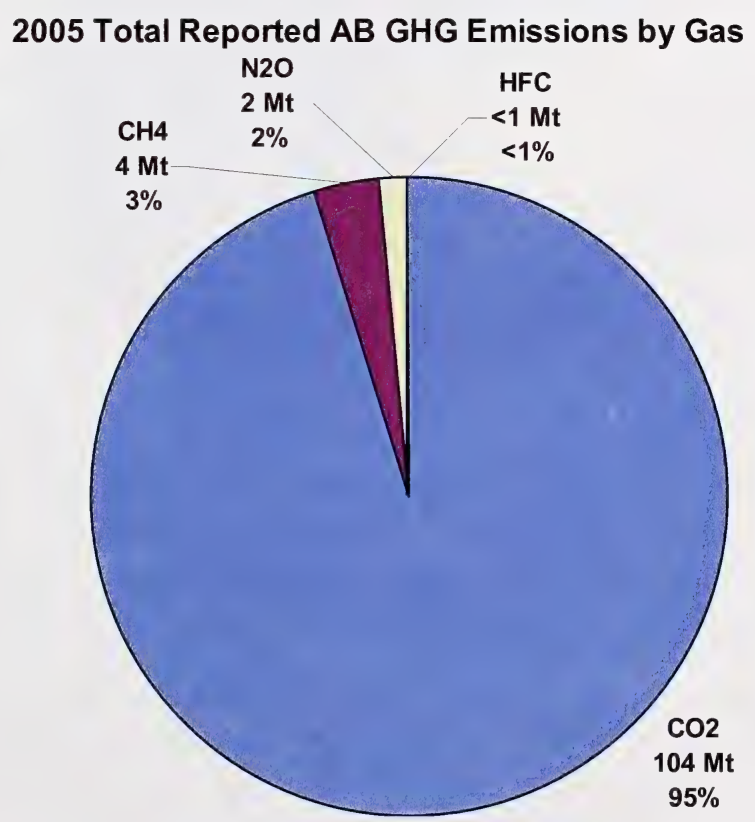

Figure 1: 2005 reported Alberta GHG emissions by gas. 


\subsection{Total GHG emissions by facility type}

Power plants were the largest source of greenhouse gas emissions in Alberta for the 2005 reporting year (see: Figure 2). A total of $51 \mathrm{Mt}$ of greenhouse gas emissions were reported by power plant facilities. This accounted for 47 per cent of all Alberta greenhouse gas emissions reporting for the 2005 reporting year. Oil sands facilities were the second largest emitter of greenhouse gases with $20 \mathrm{Mt}$, which represents 19 per cent of the reported greenhouse gas emissions. Gas plant (nine Mt, eight per cent), chemicals (seven Mt, six per cent) and heavy oil facilities (seven Mt, six per cent) were also large sources of reported greenhouse gas emissions. In Figure 2, coal-mining, forest products, landfill, cement/lime, pipeline, petroleum refining and fertilizer facilities were included in the "other" category ( $16 \mathrm{Mt}, 14$ per cent). Figure 2 presents the reported greenhouse gas emissions by facility type. The 10 largest emitting facilities were from the power plant, oil sands, heavy oil, chemicals and pipeline sectors.

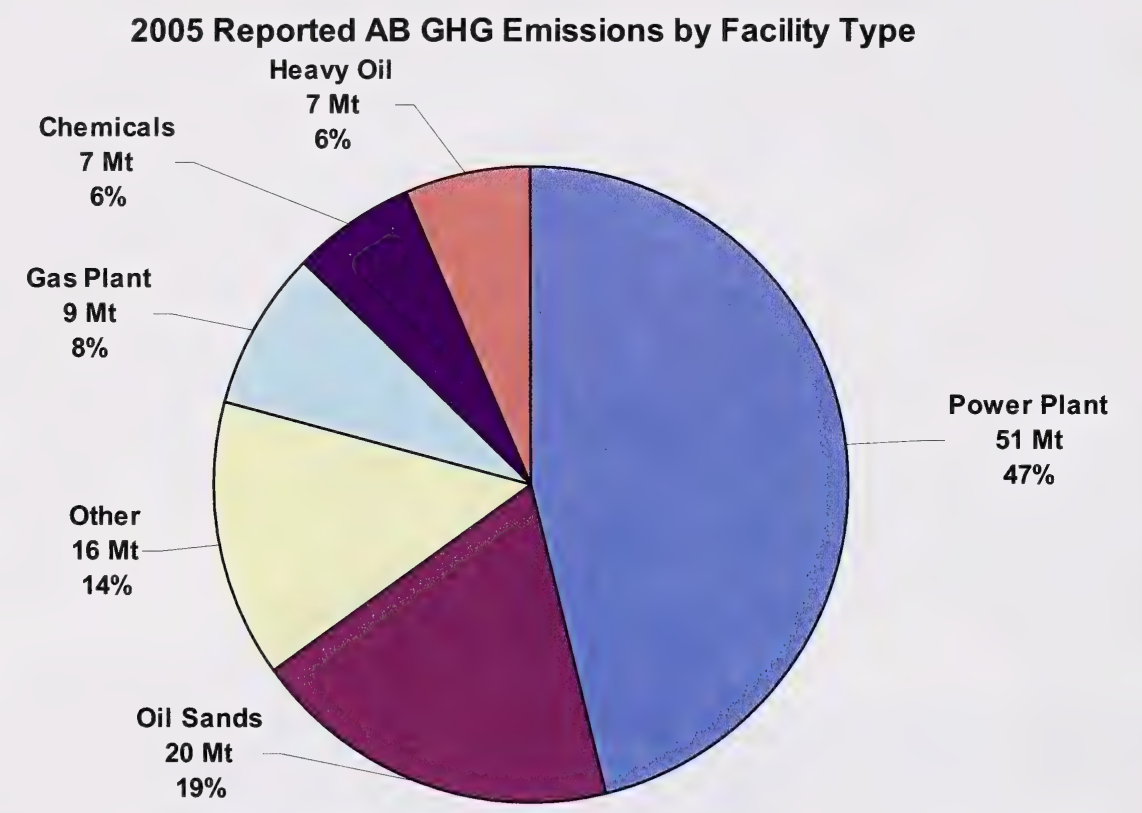

Figure 2: 2005 reported Alberta GHG emissions by facility type.

There were 101 Alberta facilities that reported greenhouse gas emissions for 2005 greenhouse gas reporting. The largest number of Alberta facilities that reported greenhouse gas emissions for the 2005 reporting year were gas plants (33). There were 21 Alberta power plants and 11 chemical facilities that reported greenhouse gas emissions for 2005 reporting. The remaining facility types each had six or fewer facilities reporting greenhouse gas emissions. Figure 3 provides an overview of the number of Alberta facilities that reported greenhouse gas emissions by facility type. 


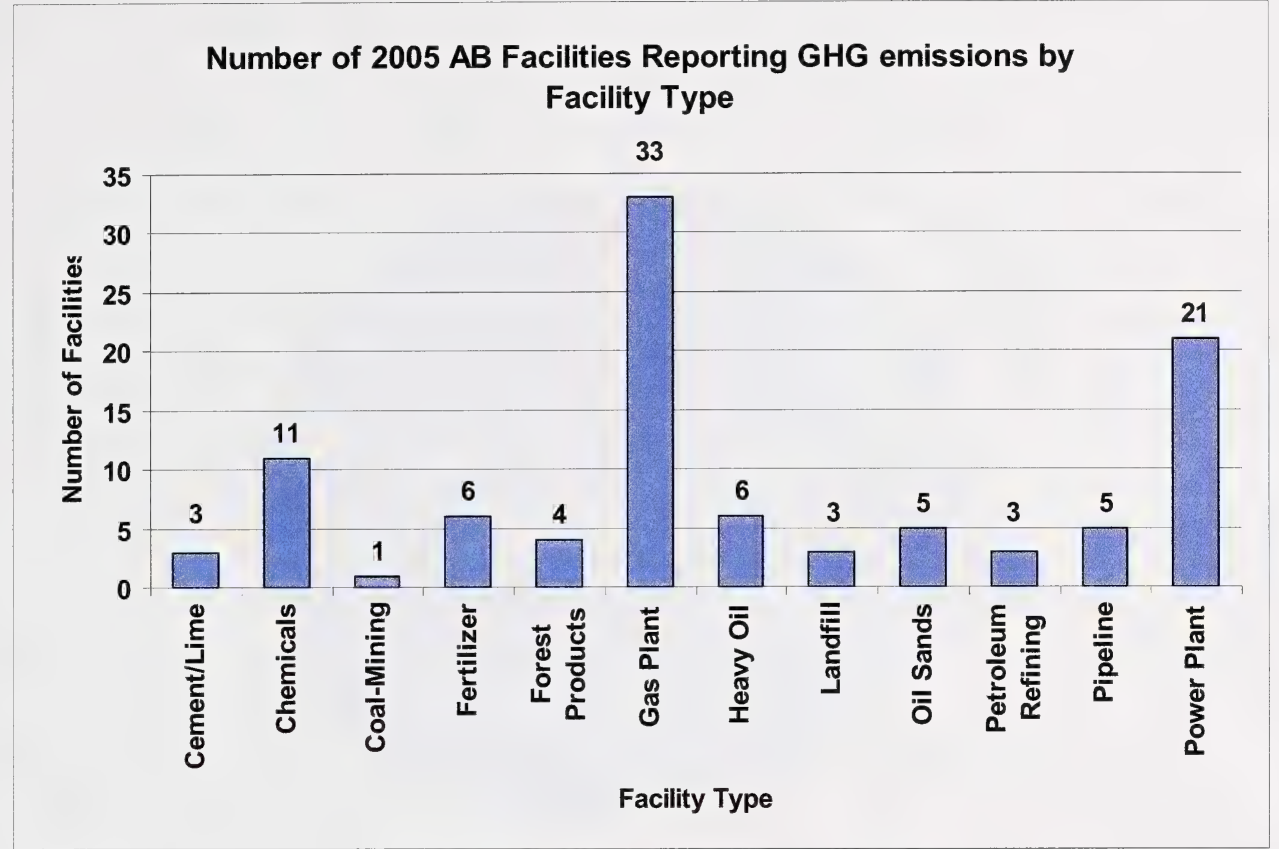

Figure 3: Number of 2005 Alberta facilities reporting GHG emissions by facility type.

\subsection{Emissions by GHG Gas type}

\subsubsection{Carbon dioxide emissions}

Power plants were the largest source of carbon dioxide $\left(\mathrm{CO}_{2}\right)$ emissions for the 2005 reporting year, with a total of $50 \mathrm{Mt}$ of $\mathrm{CO}_{2}$ emissions (see: Figure 4). This accounted for 47 per cent of all Alberta $\mathrm{CO}_{2}$ emissions reported for 2005. Oil sands facilities were the second largest emitter of $\mathrm{CO}_{2}$ with $19 \mathrm{Mt}$ or 18 per cent of reported emissions. Gas plant (eight Mt, eight per cent), chemicals (seven Mt, seven per cent) and heavy oil facilities (seven Mt, seven per cent) were also large sources of reported $\mathrm{CO}_{2}$ emissions. In Figure 4 landfill, coal-mining, forest products, cement/lime, pipeline, fertilizer and petroleum refining facilities were included in the "other" category $(13 \mathrm{Mt}, 13 \%)$. Figure 4 presents the reported $\mathrm{CO}_{2}$ emissions by facility type. 


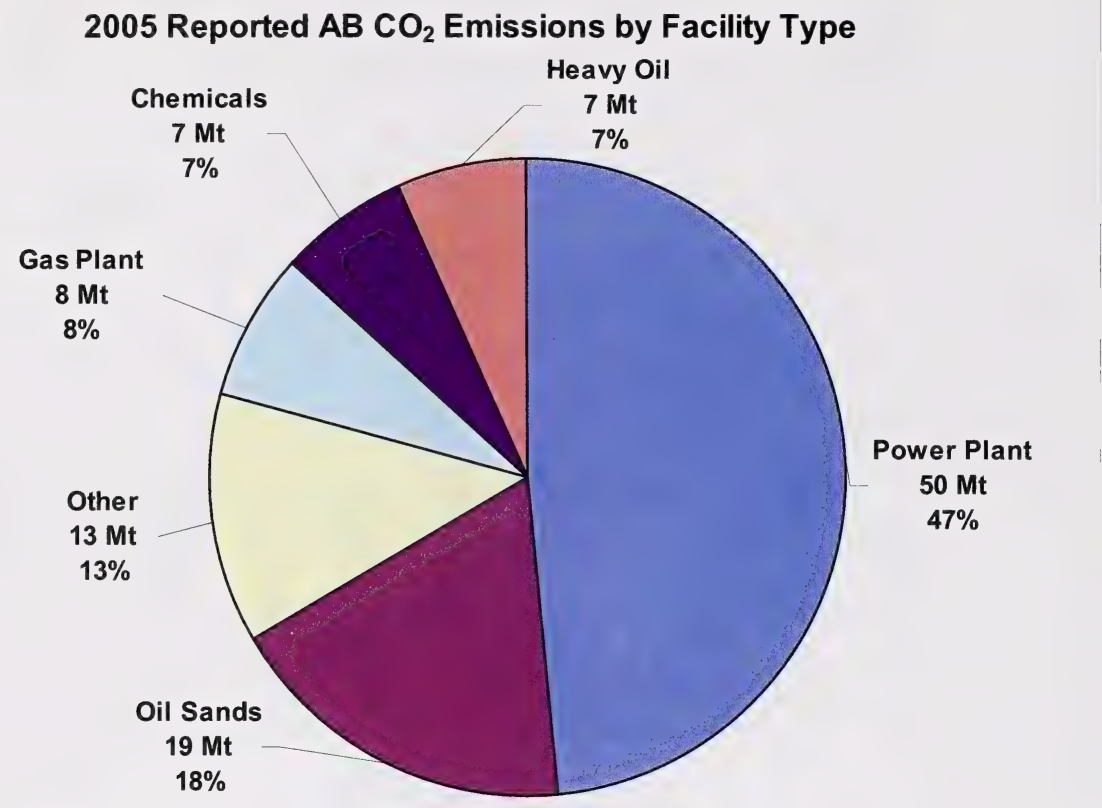

Figure 4: 2005 reported Alberta $\mathrm{CO}_{2}$ emissions by facility type.

\subsubsection{Methane emissions}

Oil sands facilities were the largest source of methane $\left(\mathrm{CH}_{4}\right)$ emissions in 2005 , with a total of $1 \mathrm{Mt}$ of $\mathrm{CH}_{4}$ emissions, which accounted for 32 per cent of all Alberta $\mathrm{CH}_{4}$ emissions being reported for 2005. Pipeline facilities reported the second largest portion of $\mathrm{CH}_{4}$ emissions ( $1 \mathrm{Mt}, 24$ per cent), followed by gas plant ( $1 \mathrm{Mt}, 19$ per cent) and landfill facilities ( $1 \mathrm{Mt}, 15$ per cent). In Figure 5 cement/lime, petroleum refining, chemicals, fertilizer, power plant, forest products, coal-mining and heavy oil facilities were included in the "other" category (less than $1 \mathrm{Mt}, 10$ per cent). Figure 5 presents the reported $\mathrm{CH}_{4}$ emissions by facility type. 


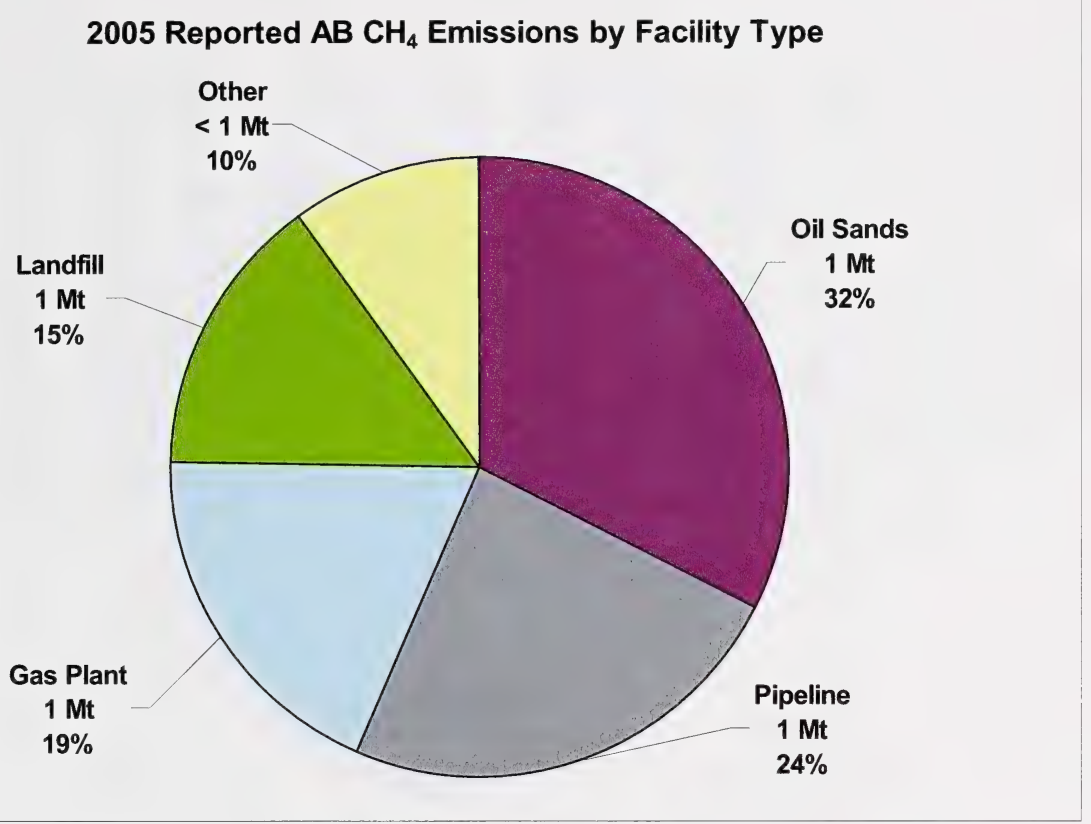

Figure 5: 2005 reported Alberta $\mathrm{CH}_{4}$ emissions by facility type.

\subsubsection{Nitrous oxide emissions}

Fertilizer facilities were the largest source of nitrous oxide $\left(\mathrm{N}_{2} \mathrm{O}\right)$ emissions reported for 2005 , with a total of $782 \mathrm{kt}$ of $\mathrm{N}_{2} \mathrm{O}$, which accounted for 48 per cent of all Alberta $\mathrm{N}_{2} \mathrm{O}$ emissions reported for 2005. Power plants were the source of the second largest portion of $\mathrm{N}_{2} \mathrm{O}$ emissions with $354 \mathrm{kt}$ or 21 per cent of reported emissions, followed by oil sands (211 kt, 13 per cent) and gas plant facilities (100 kt, 6 per cent). In Figure 6 landfill, coal-mining, cement/lime, petroleum refining, chemicals, pipeline, forest products and heavy oil facilities were included in the "other" category $(205 \mathrm{kt}, 12$ per cent). Figure 6 presents the reported $\mathrm{N}_{2} \mathrm{O}$ emissions by facility type in $\mathrm{kt}$. 


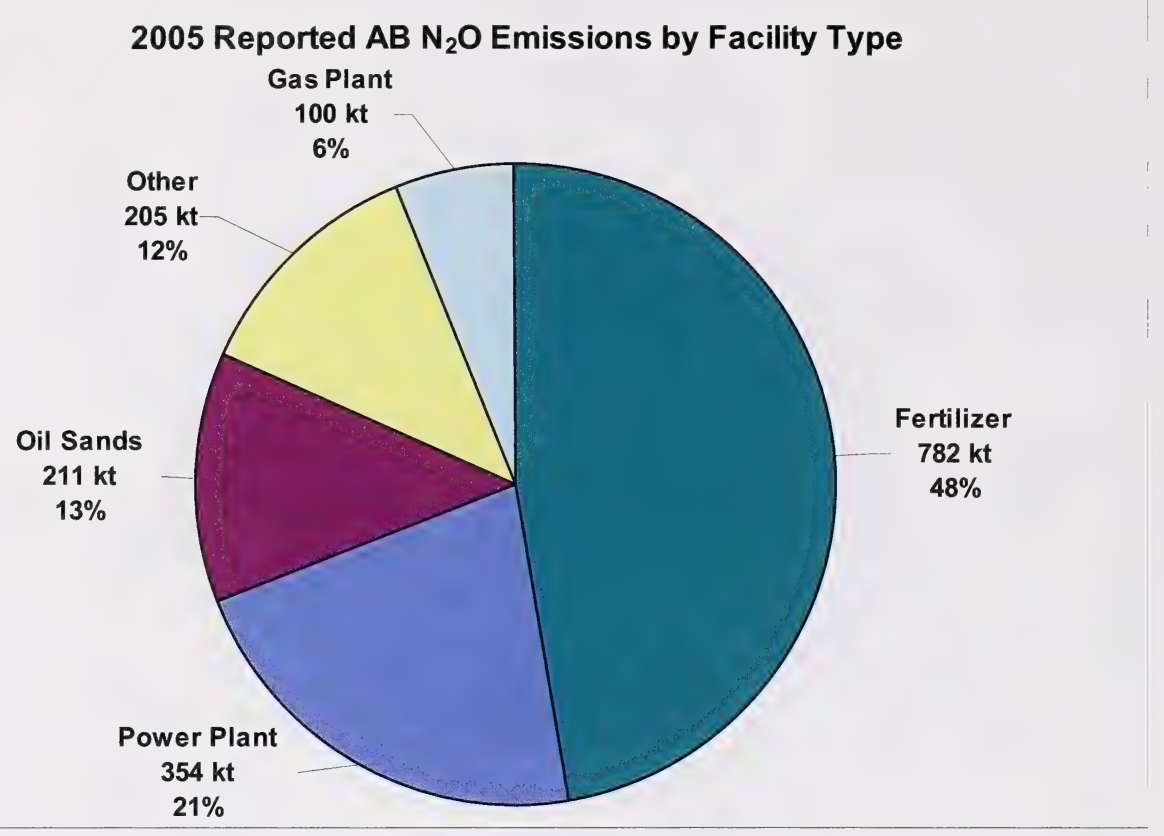

Figure 6: 2005 reported Alberta $\mathrm{N}_{2} \mathrm{O}$ emissions by facility type in kt.

\subsubsection{Emissions of hydrofluorocarbons}

Chemical facilities were the largest source of hydrofluorocarbons (HFC) reported for 2005 with a total of eight kt of HFC emissions, which accounted for more than 99 per cent of all Alberta HFC emissions reported for 2005. Petroleum refining facilities were the other source of reported HFC emissions with less than one kt of HFC emissions reported for 2005 .

\subsection{Reported emissions by facility type and GHG gas type}

For most facility types, $\mathrm{CO}_{2}$ emissions constituted the majority of reported total greenhouse gas emissions. Figure 7 presents the percentage contribution of each greenhouse gas to the total reported greenhouse gas emissions for each facility type for 2005. $\mathrm{CH}_{4}$ was a major reported greenhouse gas for coal-mining, landfill and pipeline facilities. $\mathrm{N}_{2} \mathrm{O}$ emissions were a significant source for fertilizer and forest products facilities. 


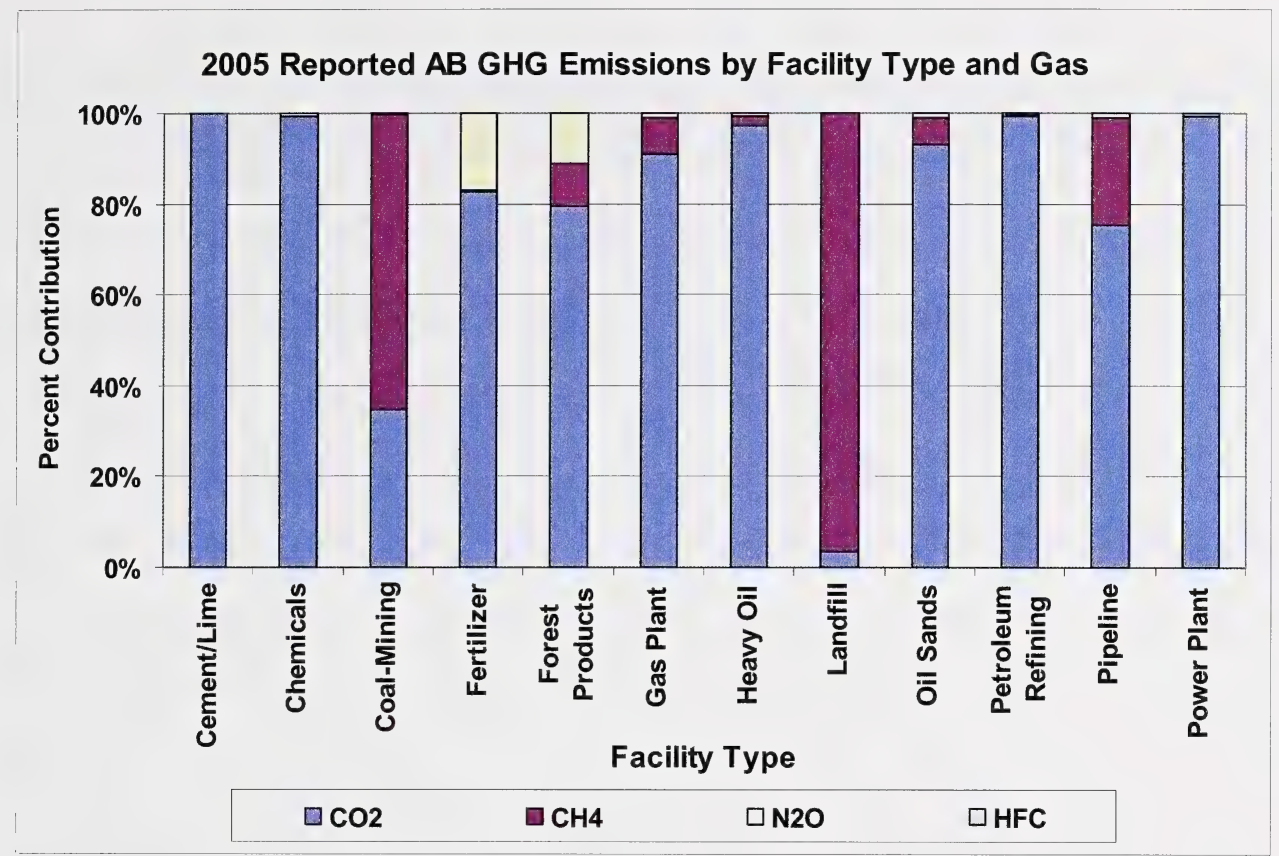

Figure 7: 2005 reported Alberta GHG emissions by facility type and gas. 


\subsection{Comparison of 2005 to 2004 GHG emissions}

The 2005 reporting year was the third year of mandatory greenhouse gas emissions reporting for large industrial facilities in the Alberta. Approximately 100 Alberta facilities reported during the first three years. The facilities reporting have varied somewhat between years, due to some facilities falling above or below the reporting threshold of $100 \mathrm{kt}$. This section of the report compares the total reported emissions between the 2004 and 2005 reporting years.

There is some question as to how comparable emissions are between the reporting years, as calculation methods and reference materials used by facilities in determining greenhouse gas emissions may change from year to year. Currently, with the information collected, it cannot be determined if a facility changed its emission calculation methodologies between reporting years.

In addition, it should be noted that industrial sectors are not required to use the same calculation methods and reference materials for the same facility types. This could mean that two similar facilities may use different methods to calculate emissions and therefore the emissions of these facilities may not be directly comparable. However, some industry associations have published recommended methodologies for their members to use to calculate greenhouse gas emissions, the use of which is voluntary.

Total reported greenhouse gas emissions were $109 \mathrm{Mt}$ for 2005. This represents a decrease of $0.1 \mathrm{Mt}$ from the $109 \mathrm{Mt}$ of greenhouse gas emissions reported for $2004^{1}$. In 2005, 101 Alberta facilities reporting greenhouse gas emissions for 2005, whereas in 200498 facilities reported greenhouse gas emissions. The increase was seen with chemicals (one), landfill (two) and power plant (two) facility types. The number of gas plant facilities reporting for 2005 decreased by two as compared to 2004 . Changes in the number of facilities reporting greenhouse gas emissions between years is due to facilities voluntarily reporting, changes in production or operations that affect whether a facility exceeds the reporting threshold or emission reduction programs that affect whether a facility exceeds the reporting threshold.

There were 94 Alberta facilities that reported greenhouse gas emissions in both the 2004 and 2005 reporting years. The net change in emissions for these 94 facilities was a decrease of $0.3 \mathrm{Mt}$ between 2004 and 2005, with 44 facilities reporting higher emissions for 2005 than 2004 and 50 facilities reporting lower emissions for 2005 as compared to 2004.

\footnotetext{
${ }^{1}$ Note that the 2004 emission numbers used here are different from the numbers in the report: Specified Gas Reporting: Alberta's 2004 Industrial Greenhouse Gas Emissions, due to facility reporting errors that in the meantime have been corrected.
} 
Table 2: 2004 and 2005 comparable facilities seeing higher or lower emissions.

\begin{tabular}{|l|c|c|c|}
\hline Facility Type & \multicolumn{2}{|c|}{$\begin{array}{c}\text { Comparable Facilities } \\
\text { Cacilities Reporting } \\
\text { Higher Emissions }\end{array}$} & $\begin{array}{c}\text { Facilities Reporting } \\
\text { Lower Emissions }\end{array}$ \\
\hline Cement/Lime & 3 & 1 & 2 \\
\hline Chemicals & 10 & 6 & 4 \\
\hline Coal-Mining & 1 & 1 & 0 \\
\hline Fertilizer & 6 & 3 & 3 \\
\hline Forest Products & 4 & 1 & 3 \\
\hline Gas Plant & 32 & 14 & 18 \\
\hline Heavy Oil & 6 & 3 & 3 \\
\hline Landfill & 1 & 1 & 0 \\
\hline Oil Sands & 5 & 0 & 2 \\
\hline Petroleum Refining & 3 & 1 & 0 \\
\hline Pipeline & 5 & 5 & 10 \\
\hline Power Plant & 18 & 8 & 50 \\
\hline Total: & 94 & 44 & \multicolumn{1}{|c|}{} \\
\hline
\end{tabular}




\subsection{National GHG Reporting}

\subsection{5 reported GHG emissions by province}

The National Mandatory Greenhouse Gas Reporting Program ${ }^{v i}$ collected reported greenhouse gas emissions data for all large industrial facilities emitting more than $100 \mathrm{kt}$ of greenhouse gas emissions. Of the $280 \mathrm{Mt}$ of total Canadian greenhouse gas emissions reported for 2005, Alberta had the highest reported emissions with $109 \mathrm{Mt}$ or 39 per cent of the total reported emissions. Ontario was the second largest emitting province of reported emissions with $78 \mathrm{Mt}$ or 28 per cent of reported greenhouse gas emissions followed by Saskatchewan ( $23 \mathrm{Mt}$, eight per cent), Quebec ( $22 \mathrm{Mt}$, eight per cent), British Columbia (14 Mt, five per cent) and New Brunswick (13 Mt, five per cent). Figure 8 shows the percentage contribution of each province/territory to 2005 total reported Canadian greenhouse gas emissions. In Figure 8 emissions reported by facilities in Nova Scotia, Newfoundland \& Labrador, Manitoba, Northwest Territories and Prince Edward Island were included in the "other" category (21 Mt).

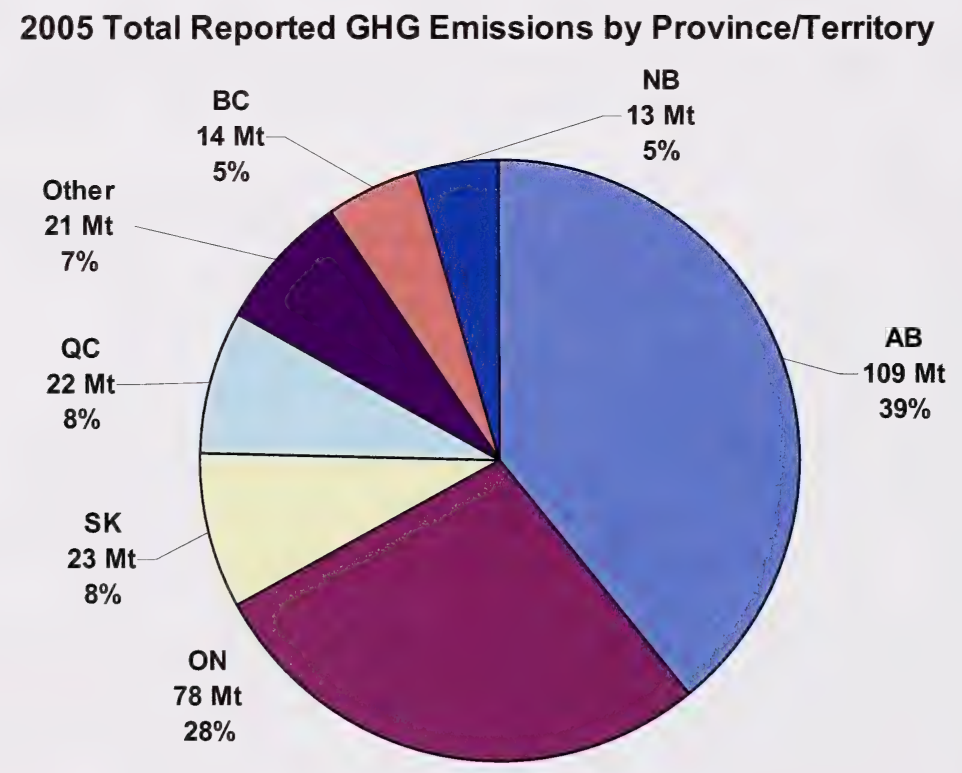

Figure 8: 2005 total reported GHG emissions by province/territory.

\subsubsection{Reported carbon dioxide emissions by province}

Of the $261 \mathrm{Mt}$ of total reported carbon dioxide $\left(\mathrm{CO}_{2}\right)$ emissions reported for 2005 greenhouse gas reporting, Alberta was the source of the largest share of reported emissions with $104 \mathrm{Mt}$ or 40 per cent of the reported emissions followed by Ontario (72 Mt, 28 per cent), Saskatchewan (22 Mt, eight per cent), Quebec (19 Mt, seven per 
cent), New Brunswick (13 Mt, five per cent) and British Columbia (12 Mt, five per cent). Figure 9 shows the percentage contribution of each province/territory to 2005 total reported Canadian $\mathrm{CO}_{2}$ emissions. In Figure 9 emissions reported by facilities in Nova Scotia, Newfoundland \& Labrador, Manitoba, Northwest Territories and Prince Edward Island were included in the "other" category (19 Mt).

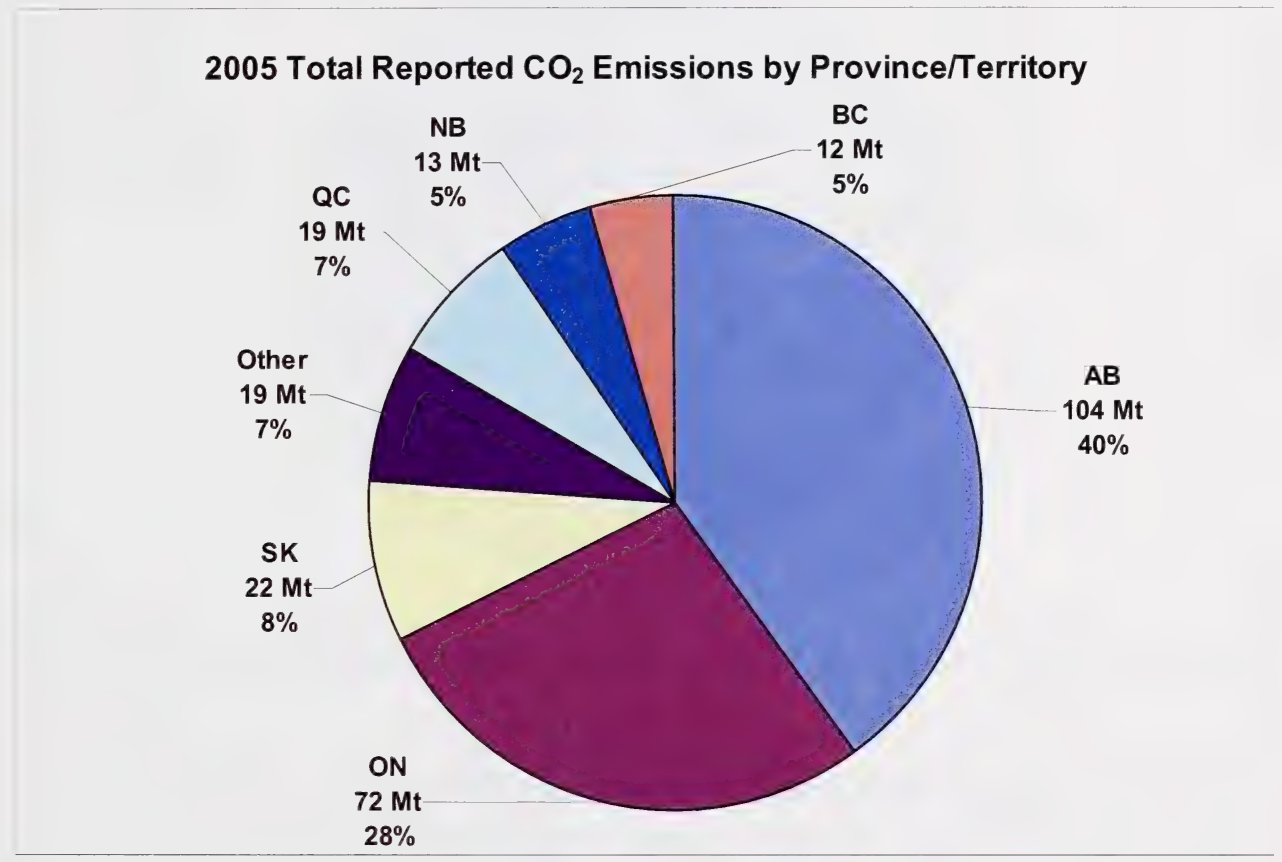

Figure 9: 2005 total reported $\mathrm{CO}_{2}$ emissions by province/territory.

\subsubsection{Reported methane emissions by province}

Of the nine Mt of total methane $\left(\mathrm{CH}_{4}\right)$ emissions reported for 2005 greenhouse gas reporting, Alberta was the source of the largest share of reported emissions with four $\mathrm{Mt}$ or 43 per cent followed by Ontario (two Mt, 23 per cent), British Columbia (one Mt, 11 per cent), Saskatchewan (one Mt, nine per cent) and Manitoba (one Mt, seven per cent). Figure 10 shows the percentage contribution of each province/territory to 2005 total reported Canadian $\mathrm{CH}_{4}$ emissions. In Figure 10 emissions reported by facilities in Quebec, Newfoundland \& Labrador, New Brunswick, Nova Scotia and the Northwest Territories were included in the "other" category (one Mt). 


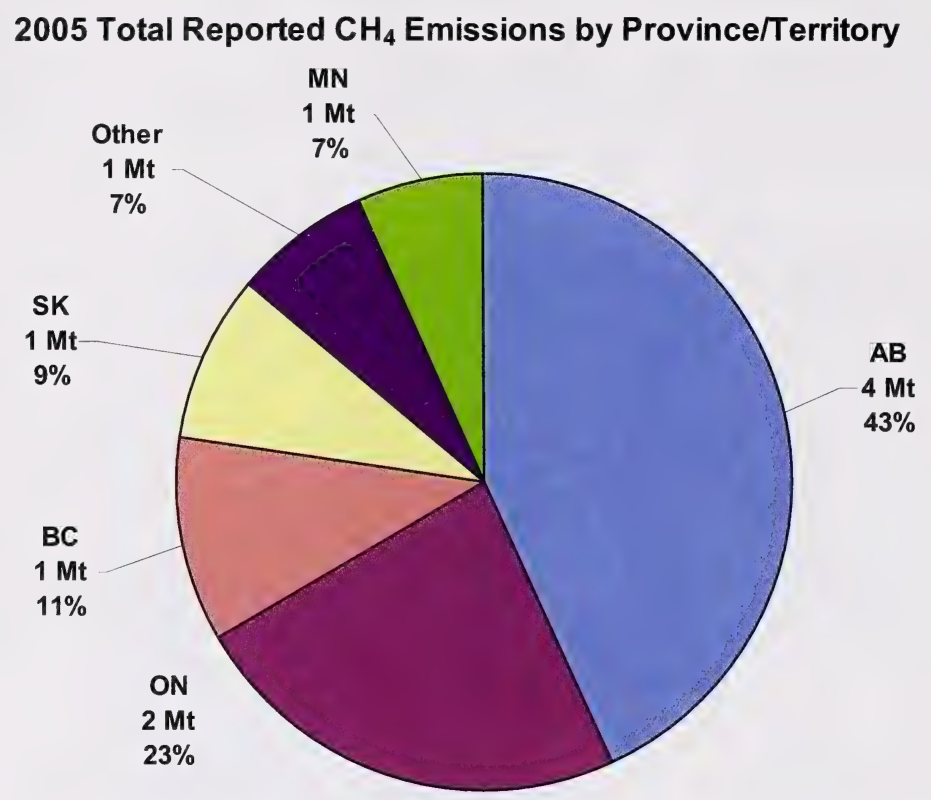

Figure 10: 2005 total reported $\mathrm{CH}_{4}$ emissions by province/territory.

\subsubsection{Reported nitrous oxide emissions by province}

Of the six Mt of total reported nitrous oxide $\left(\mathrm{N}_{2} \mathrm{O}\right)$ emissions reported for 2005 greenhouse gas reporting, Ontario was the source of the largest share of reported emissions with three Mt or 50 per cent of the reported emissions followed by Alberta (two Mt, 26 per cent), Nova Scotia (one Mt, nine per cent) and British Columbia (less than one Mt, seven per cent). Figure 11 shows the percentage contribution of each province/territory to 2005 total reported Canadian $\mathrm{N}_{2} \mathrm{O}$ emissions. In Figure 11 emissions reported by facilities in Saskatchewan, Quebec, Manitoba, New Brunswick, Newfoundland \& Labrador, Northwest Territories and Prince Edward Island were included in the "other" category (less than one Mt). 


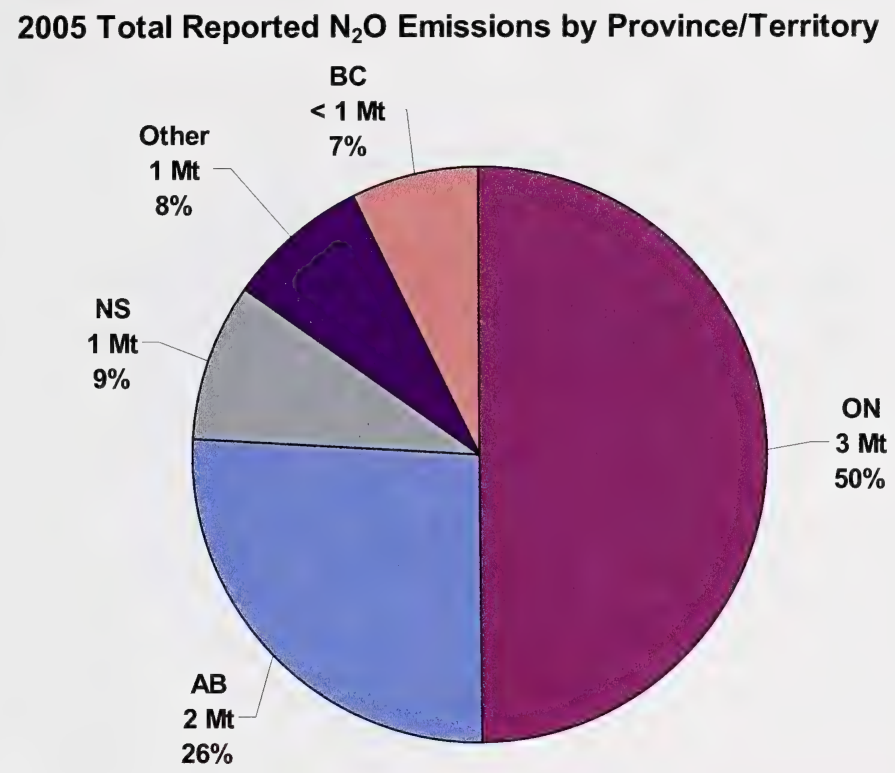

Figure 11: 2005 total reported $\mathrm{N}_{2} \mathrm{O}$ emissions by province/territory.

\subsubsection{Reported emissions of hydrofluorocarbons by province}

Of the $53 \mathrm{kt}$ of total emissions of hydrofluorocarbons (HFC) reported for 2005 greenhouse gas reporting, Quebec was the source of the largest share of reported emissions with $41 \mathrm{kt}$ or 78 per cent followed by Alberta (eight kt, 15 per cent). Figure 12 shows the percentage contribution of each province/territory to 2005 total reported Canadian HFC emissions in kt. In Figure 12, emissions reported by facilities in Newfoundland \& Labrador, Ontario, Northwest Territories, British Columbia, Manitoba and Saskatchewan were included in the "other" category (4 kt). 
2005 Total Reported HFC Emissions by Province/Territory

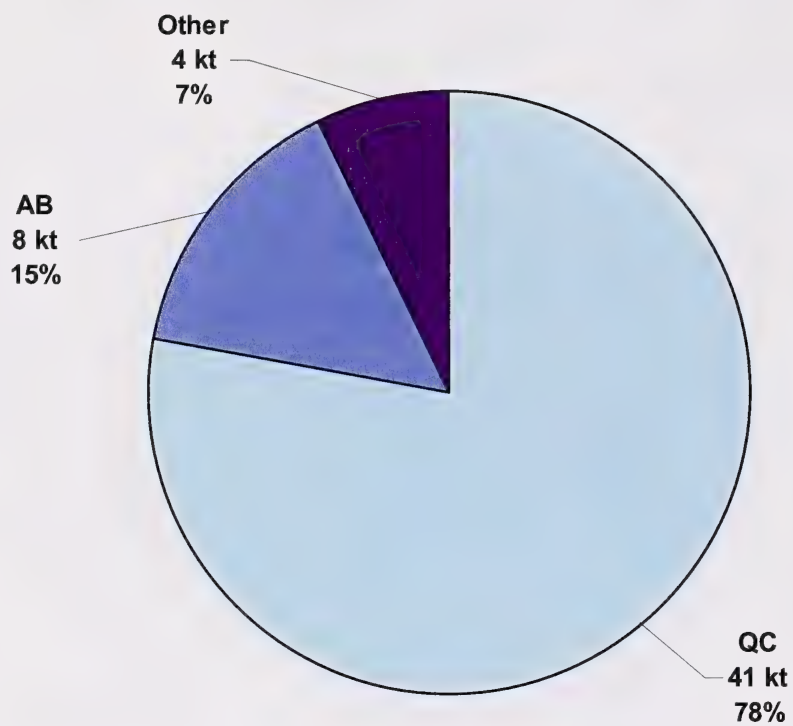

Figure 12: 2005 total reported HFC emissions by province/territory in kt. 


\subsection{Comparison to national inventory (2004)}

The National Greenhouse Gas Inventory ${ }^{\mathrm{vi}}$ is prepared in accordance with Canada's obligations under the United Nations Framework Convention on Climate Change vii (UNFCCC). The UNFCCC reporting guidelines include guidelines developed by the Intergovernmental Panel on Climate Change $e^{\text {viii }}$ that set out how greenhouse gas emissions inventories are prepared and what is included in the national inventory report. In addition to industrial sources, the National Greenhouse Gas Inventory also includes estimates of greenhouse gas emissions from other sources including transportation, agriculture, construction, commercial, institutional and residential. The National Inventory Report: Greenhouse Gas Sources and Sinks in Canada 1990-2004, which was published in April 2006, contains the most recent National Greenhouse Gas Inventory. The National Inventory includes national, provincial and territorial greenhouse gas emissions. Alberta Environment uses this Inventory and the emissions information collected through the Specified Gas Reporting Program ${ }^{i i}$ as a basis of analysis for greenhouse gas emissions and trends for Alberta. The information is used for issue identification, policy development and evaluation of current Alberta actions on climate change.

\subsection{Reporting program coverage}

The National Greenhouse Inventory ${ }^{v i i}$ provides Alberta greenhouse gas emissions from all sources; while the Specified Gas Reporting Program ${ }^{i i}$ focuses only on greenhouse gas emissions from large industrial sources in the province that meet or exceed the $100 \mathrm{kt}$ reporting threshold. The following assumes that 2004 inventory values will be within one per cent of 2005 inventory as the 2005 reported Alberta values decreased by less than one per cent.

- The 2004 National Greenhouse Gas Inventory estimated total 2004 Alberta greenhouse gas emissions of $235 \mathrm{Mt}$, while the 2005 reported greenhouse gas emissions from the Specified Gas Reporting Program were $109 \mathrm{Mt}$. Therefore the current Specified Gas Reporting Program is capturing about 47 per cent of all the greenhouse gas emissions in the province.

- Total Alberta carbon dioxide $\left(\mathrm{CO}_{2}\right)$ emissions estimated in the 2004 National Greenhouse Inventory were $184 \mathrm{Mt}$, while total reported $\mathrm{CO}_{2}$ emissions were 104 Mt. Therefore, the current Alberta Specified Gas Reporting Program is capturing 57 per cent of all $\mathrm{CO}_{2}$ emissions in the province.

- Total Alberta methane $\left(\mathrm{CH}_{4}\right)$ emissions estimated in the National Inventory were $40 \mathrm{Mt}$, while reported $\mathrm{CH}_{4}$ emissions were $3.7 \mathrm{Mt}$. The current Reporting Program is therefore capturing nine per cent of all $\mathrm{CH}_{4}$ emissions in the province. 
- Total Alberta nitrous oxide $\left(\mathrm{N}_{2} \mathrm{O}\right)$ emissions estimated in the National Inventory were $11 \mathrm{Mt}$, while $\mathrm{N}_{2} \mathrm{O}$ reported emissions were $1.7 \mathrm{Mt}$. The current Reporting Program is therefore capturing 15 per cent of $\mathrm{N}_{2} \mathrm{O}$ emissions in the province.

- Industrial sources in Alberta accounted for in the 2004 National Greenhouse Gas Inventory totalled $172 \mathrm{Mt}$ or 73 per cent of total greenhouse gas emissions. Total reported 2005 greenhouse gas emissions in Alberta were 109 Mt. The current Specified Gas Reporting Program is therefore capturing 64 per cent of the total industrial greenhouse gas emissions in the province.

\subsection{Greenhouse gases}

A total of $235 \mathrm{Mt}$ of greenhouse gases were emitted from all sources in Alberta according to the 2004 National Greenhouse Gas Inventory $y^{v i i}$. Of these emissions, $184 \mathrm{Mt}$ or 78 per cent were in the form of carbon dioxide $\left(\mathrm{CO}_{2}\right)$. Forty Mt or 17 per cent of total greenhouse gas emissions were in the form of methane $\left(\mathrm{CH}_{4}\right)$. The remaining five per cent or $11 \mathrm{Mt}$ of greenhouse gas emissions in Alberta were in the form of nitrous oxide $\left(\mathrm{N}_{2} \mathrm{O}\right)$. There were no significant sources of emissions of hydrofluorocarbons (HFC), perfluorocarbons ( $\mathrm{PFC})$ or sulphur hexafluoride $\left(\mathrm{SF}_{6}\right)$ in Alberta according to the National Inventory. Figure 13 shows the total 2004 greenhouse gas emissions in Alberta by gas.

2004 AB GHG Emissions from All Sources (National Inventory)

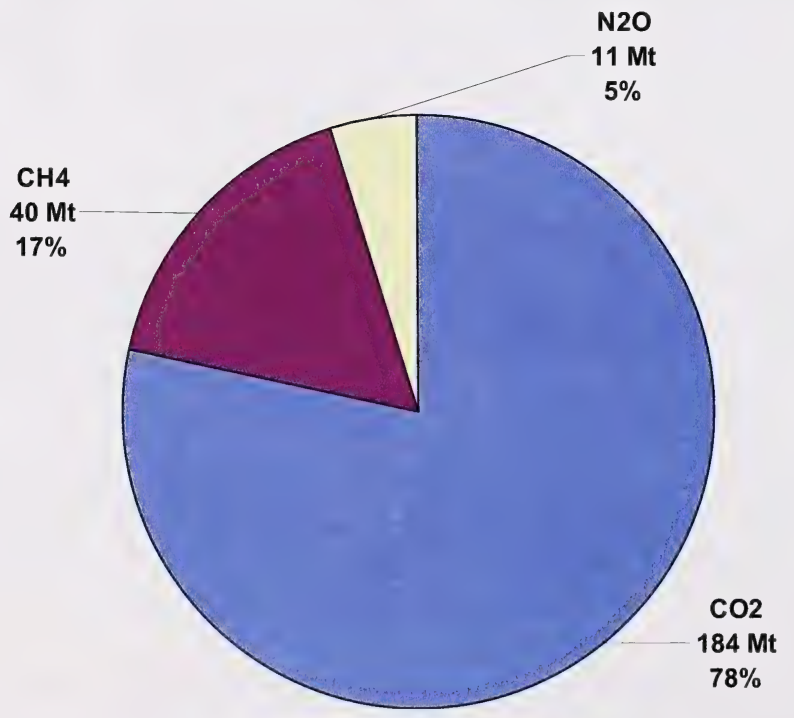

Figure 13: 2004 Alberta GHG emissions from all sources (National Inventory). 


\subsection{Largest greenhouse gas sources}

Six sources were responsible for the majority ( $210 \mathrm{Mt}, 89$ per cent) of the total of 2004 greenhouse gas emissions (235 Mt). Fossil fuel industries including pipelines and fugitive sources from coal mining and oil and natural gas were the largest source of greenhouse gas emissions in Alberta $(87 \mathrm{Mt}, 37$ per cent). Electricity and heat generation were the second largest sources of greenhouse gas emissions in Alberta with (53 Mt, 22 per cent) followed by transportation sources excluding pipelines (30 Mt, 13 per cent), agriculture (17 Mt, seven per cent), industrial processes (13 Mt, six per cent) and mining (11 Mt, five per cent). The remaining sources of greenhouse gases in Alberta accounted for the $25 \mathrm{Mt}$ or 11 per cent of total 2004 greenhouse gas emissions. 


\subsection{GHG trends since 1990}

Alberta has set a target of a 50 per cent emissions intensity reduction below 1990 levels by 2020 . Emissions intensity is a measure of the quantity of greenhouse gas emissions (in kilotonnes) compared to the size of the Alberta gross domestic product (in dollars). An interim target of a 30 per cent reduction in intensity by 2010 was also established. Greenhouse gas emissions intensity is also reported as one of Alberta's State of the Environment ${ }^{i x}$ performance indicators.

Total absolute Alberta inventory greenhouse gas emissions from all sources have increased by $67 \mathrm{Mt}$ or 40 per cent between 1990 and 2004 (from $168 \mathrm{Mt}$ to $235 \mathrm{Mt}$ ). Figure 14 shows the total Alberta greenhouse gas emissions from 1990 to 2004 . All provinces and territories except the Yukon have seen greenhouse gas emissions increase between 1990 and 2004. Alberta's 40 per cent increase was the third largest after Saskatchewan (62 per cent) and New Brunswick (47 per cent).

While total absolute greenhouse gas emissions have been increasing in Alberta, emissions intensity of greenhouse gas emissions improved by 16 per cent (see: Figure 15). Alberta is more than one quarter of the way to meeting its target of reducing emissions intensity by 50 per cent below 1990 levels. Furthermore, Alberta is over half way to meeting its interim 2010 target of a 30 per cent reduction.

Alberta's total greenhouse gas emissions were $168 \mathrm{Mt}$ in 1990 with Alberta's Gross Domestic Product at \$82,227 million dollars (1997 dollars) in 1990. The ratio of the greenhouse gas emissions per GDP gives an intensity value of 2.04 for 1990. In 2004 Alberta's total greenhouse gas emissions were $235 \mathrm{Mt}$ with a GDP of $\$ 135,837$ million dollars (1997 dollars). The ratio of the greenhouse gas emissions per GDP gives an intensity value of 1.73 in 2004 . Although Alberta's total greenhouse gas emissions have increased since 1990, the province's economy has grown at a much faster rate resulting in an improvement in emissions intensity. 


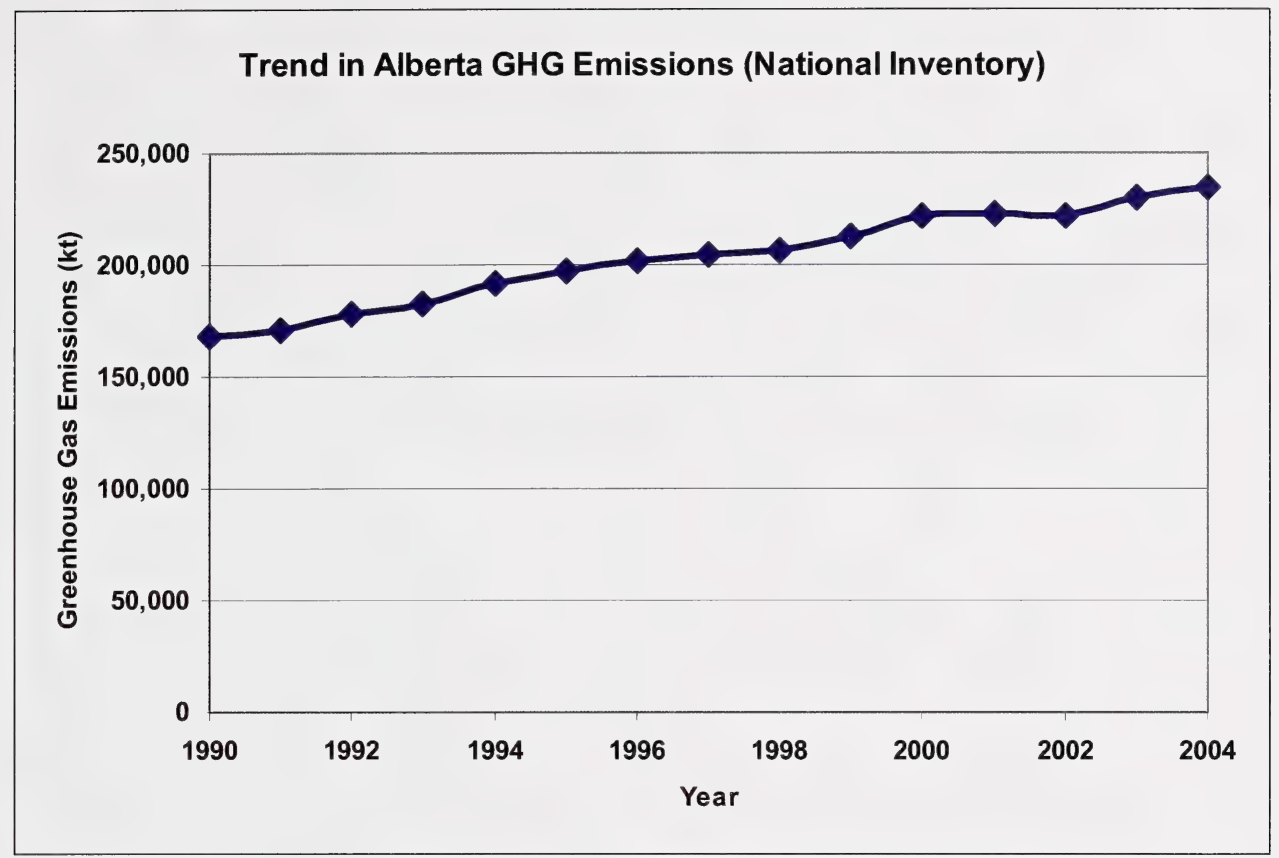

Figure 14: Trends in Alberta greenhouse gas emissions (National Inventory).

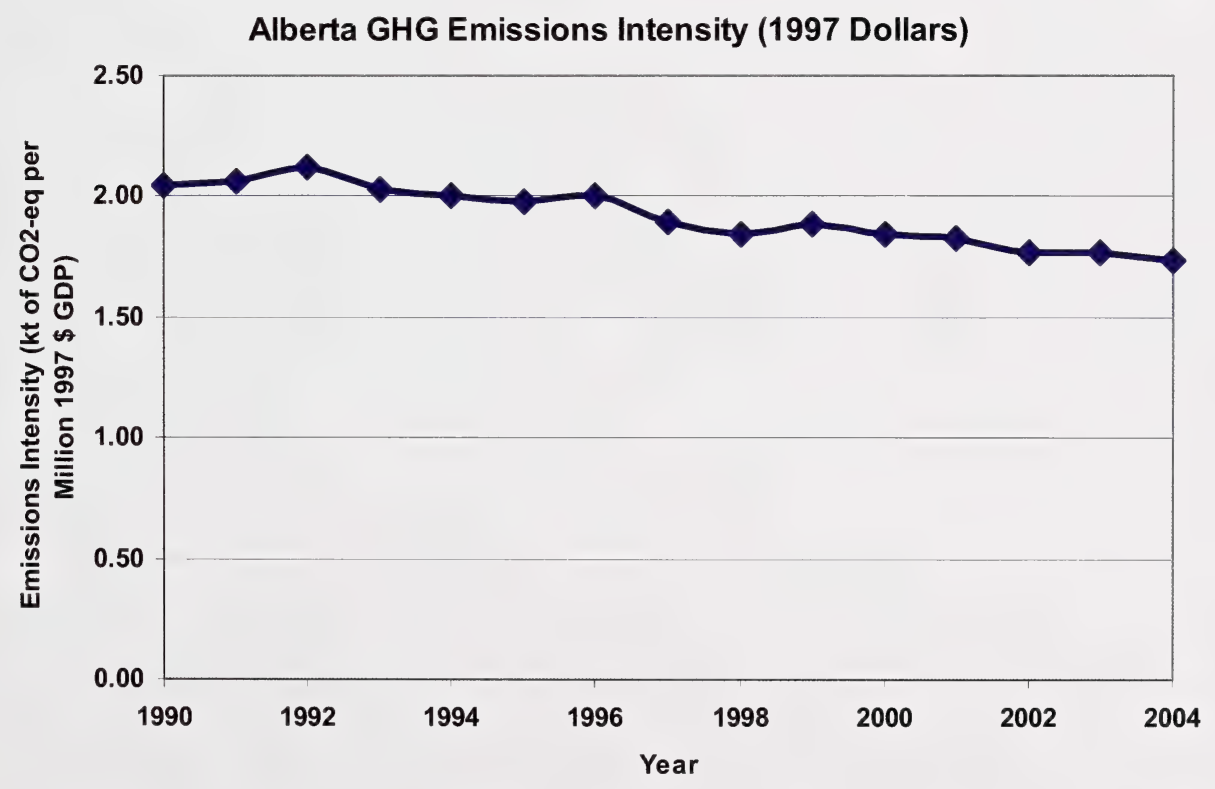

Figure 15: Alberta GHG emissions intensity (1997 Dollars). 
Appendix 


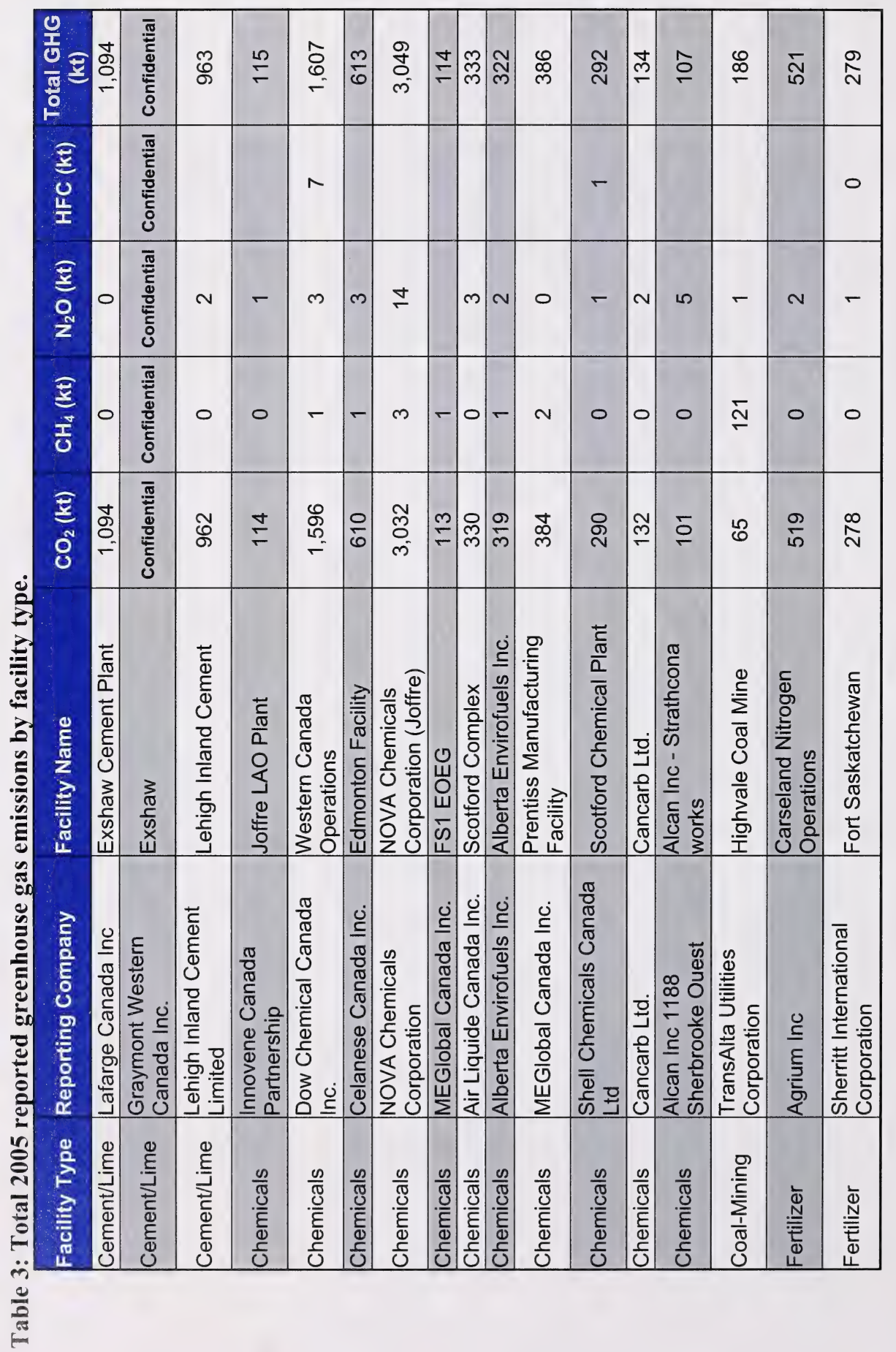




\begin{tabular}{|c|c|c|c|c|c|c|c|c|c|c|c|c|c|c|c|c|c|c|}
\hline F & $\begin{array}{l}\hat{m} \\
\stackrel{\sigma}{\sigma}\end{array}$ & 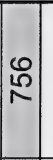 & $\begin{array}{l}0 \\
\stackrel{0}{0} \\
\stackrel{-}{r}\end{array}$ & 웅 & ભొ & 夺 & னே & $\infty$ & 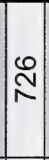 & f & $\stackrel{m}{m}$ & 㣽 & Lิ & లై & $\mid \begin{array}{l}\infty \\
1 \\
\omega\end{array}$ & న్లి & స్ & 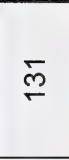 \\
\hline 6 & & & & & & & & & & & & & & & & & & \\
\hline 2 & 10 & 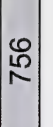 & 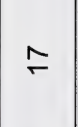 & $\sim$ & $\mp$ & $\mp$ & $\stackrel{9}{-}$ & $\mp$ & $\nabla$ & 0 & - & 100 & $\sim c$ & $0 \sim$ & 0 & $\sim$ & $\sim$ & - \\
\hline 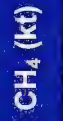 & 0 & & $\infty$ & - & ల్లి & - & $\sim$ & 으 & 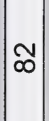 & - & $\stackrel{m}{\sim}$ & $\bar{m}$ & $\pm \stackrel{\infty}{~}$ & $\stackrel{\sim}{\infty} \infty$ & $\begin{array}{l}\infty \\
\infty\end{array}$ & 采 & $\nabla$ & 10 \\
\hline ก & $\begin{array}{l}\text { ָ̃ } \\
\underset{\sim}{-}\end{array}$ & 0 & 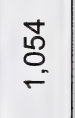 & જ̊ & ๙ૅ & 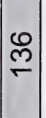 & R & ชิ & 웅 & $\mathscr{m}$ & $\stackrel{\Omega}{\leftarrow}$ & $\underset{\sim}{\sim}$ & $\begin{array}{l}\text { 인 } \\
\end{array}$ & ঠ্ণী & 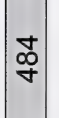 & $\underset{\sim}{ \pm}$ & 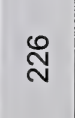 & $\stackrel{L}{\sim}$ \\
\hline$\stackrel{\Xi}{\Xi}$ & 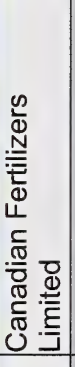 & 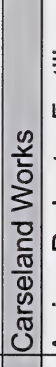 & 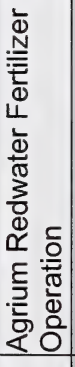 & 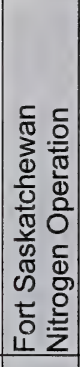 & 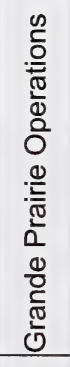 & \begin{tabular}{|c} 
\\
윽 \\
0 \\
$\frac{2}{0}$ \\
$\frac{0}{1}$ \\
I \\
\end{tabular} & 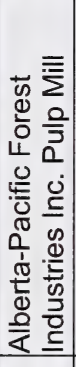 & 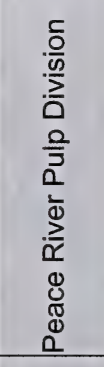 & 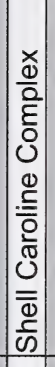 & 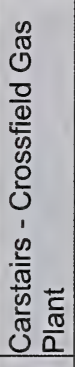 & 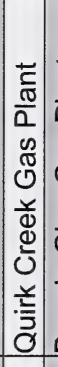 & 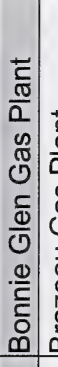 & 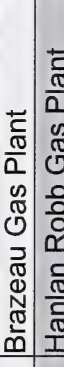 & 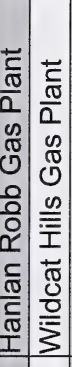 & 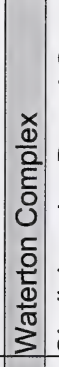 & 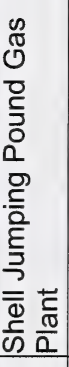 & 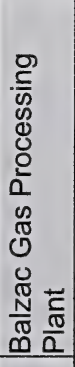 & 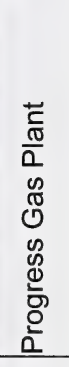 \\
\hline 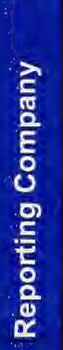 & 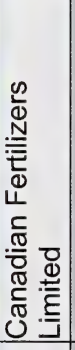 & 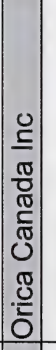 & 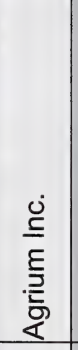 & 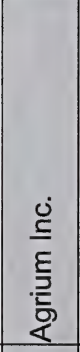 & 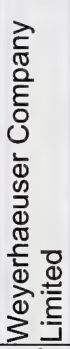 & 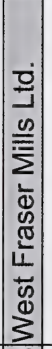 & 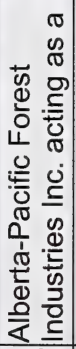 & 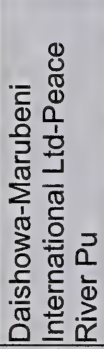 & 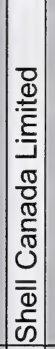 & 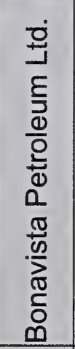 & 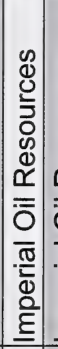 & 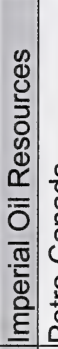 & 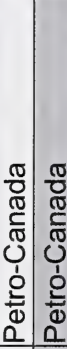 & 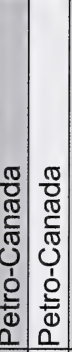 & 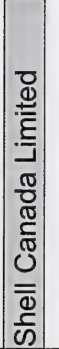 & 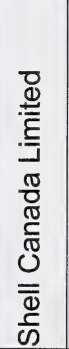 & 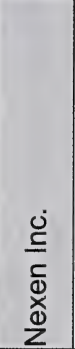 & 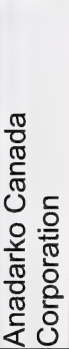 \\
\hline$\frac{\sum_{0}^{\circ}}{\frac{2}{2}}$ & 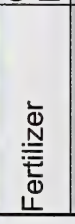 & 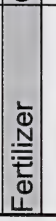 & 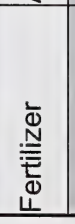 & 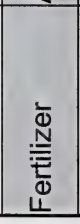 & $\begin{array}{l}0 \\
0 \\
0 \\
0 \\
0 \\
0 \\
0 \\
5 \\
0 \\
0 \\
\\
\end{array}$ & 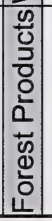 & 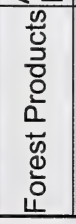 & 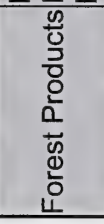 & 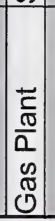 & 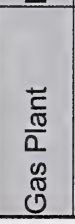 & 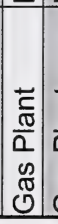 & $\begin{array}{c}\frac{7}{0} \\
\frac{\pi}{0} \\
0 \\
\mathbb{0} \\
0 \\
0\end{array}$ & 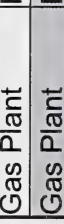 & 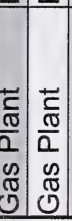 & \begin{tabular}{|c|}
$\vec{c}$ \\
$\frac{\pi}{0}$ \\
0 \\
$\tilde{g}$ \\
$\tilde{0}$ \\
\end{tabular} & $\begin{array}{l}\frac{\pi}{\frac{\pi}{\pi}} \\
\frac{\pi}{0} \\
\mathscr{0} \\
\mathbb{0} \\
0\end{array}$ & $\begin{array}{l}\frac{\pi}{C} \\
\frac{\pi}{0} \\
\frac{0}{2} \\
0 \\
0 \\
\end{array}$ & 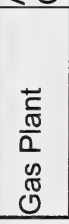 \\
\hline
\end{tabular}




\begin{tabular}{|c|c|c|c|c|c|c|c|c|c|c|c|c|c|c|c|c|c|c|}
\hline$\frac{\frac{0}{6}}{\frac{10}{8}}=$ & ஓ & $\stackrel{\infty}{\leftarrow}$ & $\hat{\mathbf{N}}$ & ก็ & প & مٌ & $\stackrel{\infty}{\mp}$ & छ్ & ิㅡㅁ & 占 & ळ̆ & $\stackrel{\sim}{\sim}$ & 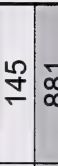 & $\stackrel{\mathbb{N}}{\mathrm{N}}$ & $\stackrel{\overbrace{}}{\sim}$ & 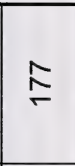 & $\begin{array}{l}\infty \\
\stackrel{\infty}{ } \\
\sim\end{array}$ & $\frac{m}{N}$ \\
\hline$=$ & & & & & & & & & & & & & & & & & & \\
\hline$\frac{1}{0}$ & $N$ & $r$ & $\nabla$ & 6 & 0 & $N$ & $\mp$ & $\nabla$ & م & $m$ & $\nabla$ & $m$ & $\sim \curvearrowright$ & $r$ & 0 & $m$ & 0 & $N$ \\
\hline$\frac{\vec{t}}{\frac{1}{6}}$ & $\nabla$ & ㅇ & $\cong$ & ผ & 0 & $\stackrel{10}{\leftarrow}$ & స̃ & 0 & $\stackrel{\simeq}{\simeq}$ & $\nabla$ & 0 & $\sim$ & 8 & $R$ & 0 & $m$ & $\underset{Z}{ \pm}$ & 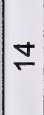 \\
\hline$\frac{\pi}{0}$ & $\stackrel{\llcorner}{\infty}$ & $\stackrel{\widehat{N}}{\sim}$ & ৫্ট & 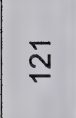 & ๙ & $\stackrel{\infty}{\text { N }}$ & மீ & है & ळ & $\stackrel{\infty}{\stackrel{\infty}{\sim}}$ & $\infty$ & స్లె & হ & $\bar{i}$ & $\stackrel{\check{N}}{\sim}$ & $\stackrel{\Sigma}{\approx}$ & 巳 & مू \\
\hline 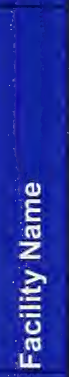 & 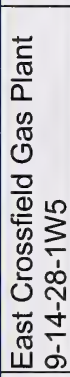 & 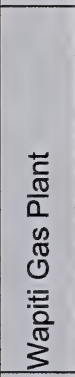 & 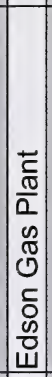 & 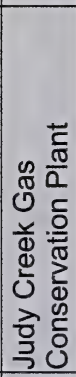 & 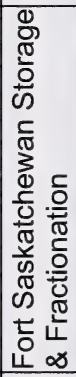 & 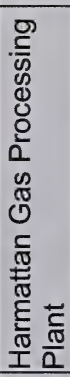 & 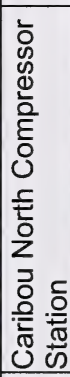 & 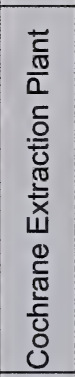 & 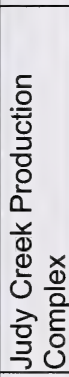 & 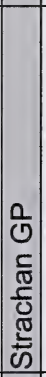 & 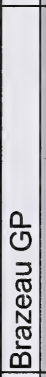 & 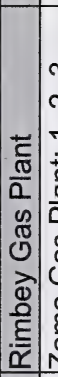 & 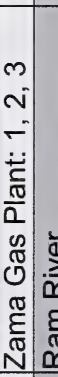 & 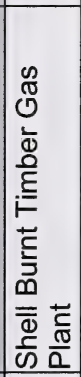 & 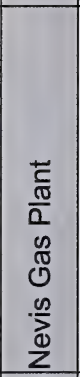 & 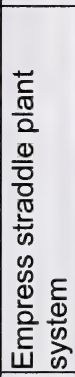 & 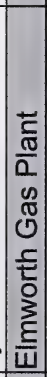 & $\mid \begin{array}{l}0 \\
0 \\
\frac{N}{1} \\
\frac{1}{2} \\
\end{array}$ \\
\hline 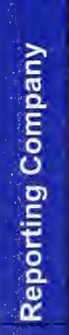 & 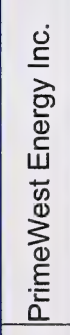 & 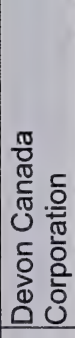 & 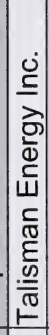 & 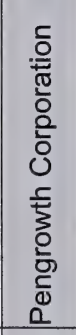 & 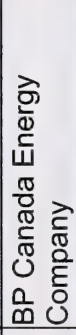 & 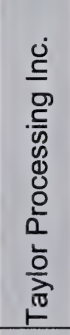 & 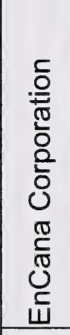 & 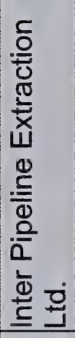 & 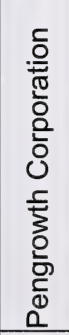 & 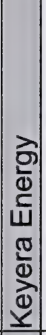 & 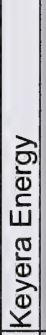 & ప্] & 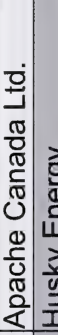 & 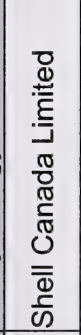 & 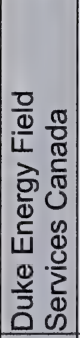 & 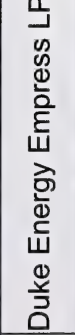 & 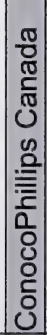 & 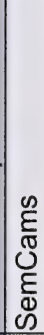 \\
\hline$\frac{2}{2}$ & $\begin{array}{l}\vec{c} \\
\frac{\pi}{0} \\
0 \\
\mathbb{0} \\
0 \\
0\end{array}$ & $\begin{array}{l}\frac{\pi}{C} \\
\frac{\pi}{0} \\
0 \\
\mathbb{8} \\
0 \\
0\end{array}$ & 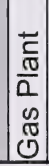 & 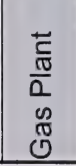 & $\begin{array}{l}\frac{\pi}{c} \\
\frac{\pi}{0} \\
0 \\
\tilde{D} \\
0\end{array}$ & $\begin{array}{l}\frac{\pi}{\pi} \\
\frac{\pi}{\pi} \\
0 \\
0 \\
0 \\
0\end{array}$ & $\begin{array}{l}\frac{\vec{c}}{c} \\
\frac{0}{0} \\
\frac{0}{0} \\
0 \\
0 \\
0\end{array}$ & $\begin{array}{l}\frac{\pi}{C} \\
\frac{\pi}{0} \\
0 \\
\mathbb{0} \\
0 \\
0\end{array}$ & $\begin{array}{l}\frac{\pi}{\frac{c}{0}} \\
\frac{\pi}{0} \\
0 \\
0 \\
0 \\
0\end{array}$ & $\mid$\begin{tabular}{|c|}
$\frac{\pi}{d 0}$ \\
$\frac{\pi}{0}$ \\
0 \\
$\mathbb{0}$ \\
0 \\
\end{tabular} & 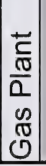 & 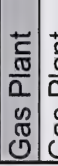 & 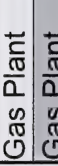 & $\begin{array}{l}\vec{T} \\
\frac{\pi}{0} \\
0 \\
0 \\
0 \\
0\end{array}$ & 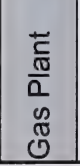 & $\begin{array}{l}\frac{\vec{c}}{\pi} \\
\frac{\pi}{0} \\
0 \\
\tilde{D} \\
0\end{array}$ & \begin{tabular}{|c|}
$\frac{T}{c}$ \\
$\frac{\pi}{0}$ \\
$\underline{0}$ \\
0 \\
0 \\
0 \\
0
\end{tabular} & $\frac{\vec{c}}{\frac{\pi}{n}}$ \\
\hline
\end{tabular}




\begin{tabular}{|c|c|c|c|c|c|c|c|c|c|c|c|c|c|c|}
\hline & & $\stackrel{8}{\leftarrow}$ & \begin{tabular}{l|l}
$\infty$ \\
$\frac{\pi}{y}$ & $\frac{y}{4}$
\end{tabular} & ల్లి & $\begin{array}{l}\bar{\infty} \\
\stackrel{\infty}{\leftarrow}\end{array}$ & ๙ิ & 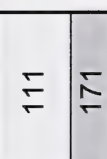 & $=\stackrel{\infty}{\sim}$ & 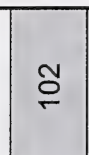 & 岕 & $\stackrel{\Re}{\leftarrow}$ & $\begin{array}{l}\hat{\omega} \\
\stackrel{0}{0} \\
\stackrel{0}{0}\end{array}$ & & A \\
\hline & & & & & & & & & & & & & & \\
\hline & & 0 & $\stackrel{\infty}{\infty} 0$ & $\stackrel{g}{\stackrel{9}{2}}$ & $\stackrel{\llcorner}{\sim}$ & 0 & 0 & & & $\cong$ & $N$ & 8 & & $\stackrel{0}{\sim} 0$ \\
\hline & & $\stackrel{\sim}{\sim}$ & $\div \mathscr{q}$ & 0 & む) & 0 & $0 \underline{\underline{\underline{\beta}}}$ & $\stackrel{\infty}{\stackrel{\infty}{\sim}}$ & $\stackrel{N}{\circ}$ & $\sigma$ & g & 8 & & o \\
\hline & 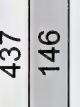 & 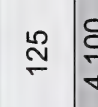 & 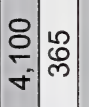 & $\bar{\sim}$ & $\begin{array}{l}\mathbb{N} \\
\stackrel{N}{\digamma}\end{array}$ & ฮ్ & $\stackrel{\circ}{=}$ న & & & 음 & ̃ & 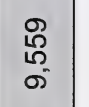 & $\stackrel{N}{N}$ & 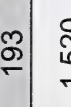 \\
\hline & 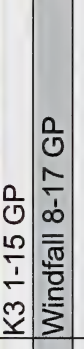 & 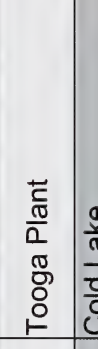 & 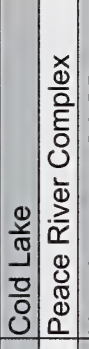 & 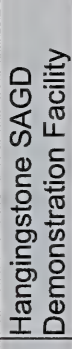 & 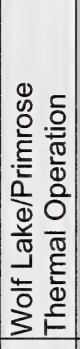 & 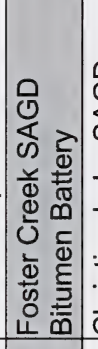 & 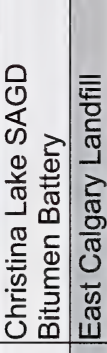 & 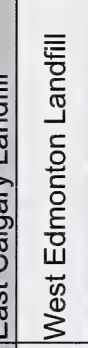 & 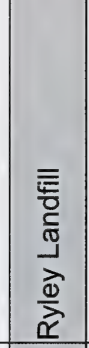 & 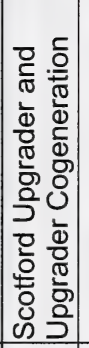 & 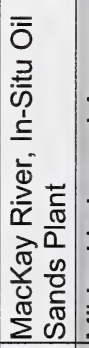 & 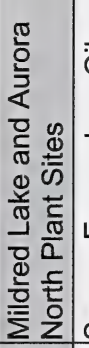 & 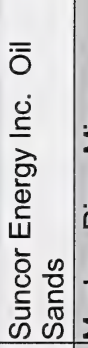 & \\
\hline & 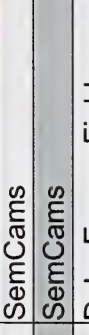 & 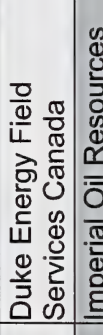 & 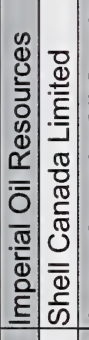 & 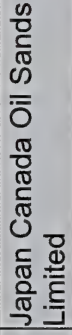 & 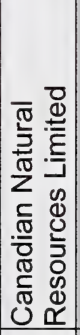 & 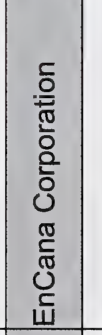 & 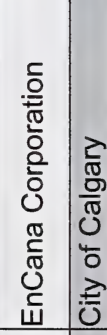 & 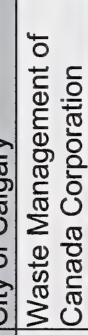 & 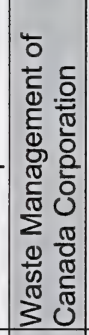 & 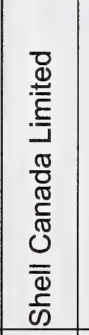 & $\begin{array}{l}\frac{\pi}{0} \\
\frac{\pi}{0} \\
\frac{\pi}{\pi} \\
0 \\
1 \\
\frac{1}{0} \\
0 \\
Q\end{array}$ & 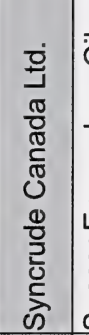 & 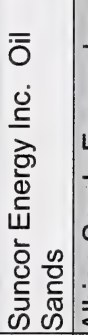 & 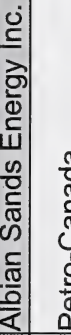 \\
\hline & 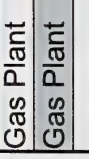 & 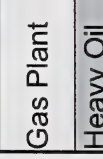 & 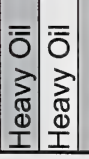 & 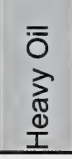 & \begin{tabular}{|l|}
$\overline{0}$ \\
3 \\
$\mathbb{0}$ \\
$\underline{I}$ \\
\end{tabular} & \begin{tabular}{|l|}
$\overline{0}$ \\
$\bar{\lambda}$ \\
$\Phi$ \\
$\Phi$ \\
\end{tabular} & 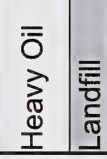 & 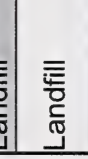 & \begin{tabular}{|l|} 
咅 \\
苛 \\
\end{tabular} & \begin{tabular}{|l} 
\\
0 \\
$\bar{c}$ \\
$\tilde{D}$ \\
$\bar{\omega}$ \\
$\overline{0}$
\end{tabular} & $\begin{array}{l}\text { on } \\
\overline{0} \\
\tilde{D} \\
\tilde{D} \\
\overline{0}\end{array}$ & $\begin{array}{l}\frac{0}{0} \\
\bar{E} \\
\infty \\
\overline{0} \\
\overline{0}\end{array}$ & $\begin{array}{l}0 \\
\bar{c} \\
\bar{N} \\
\bar{D} \\
\overline{0}\end{array}$ & \\
\hline
\end{tabular}




\begin{tabular}{|c|c|c|c|c|c|c|c|c|c|c|c|c|c|c|c|c|}
\hline$\frac{0}{\frac{10}{2}} \frac{2}{2}$ & $\frac{\infty}{\sigma}$ & 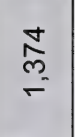 & $\overline{\grave{N}}$ & $\begin{array}{c}n \\
1 \\
15\end{array}$ & $\begin{array}{l}\text { @) } \\
\stackrel{\sim}{\sim}\end{array}$ & $\stackrel{P}{\text { N }}$ & $\overline{\text { Jे }}$ & శ్ & $\begin{array}{l}\frac{8}{9} \\
\text { g } \\
\text { in }\end{array}$ & 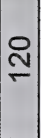 & $\stackrel{\llcorner}{\infty}$ & $\begin{array}{l}\text { D } \\
\text { م } \\
\infty\end{array}$ & $\frac{m}{\pi}$ & से & $\begin{array}{l}\text { స్ } \\
\text { గ్ } \\
0\end{array}$ & $\stackrel{10}{\sim}$ \\
\hline & & 0 & & & & & & & & & & & & & & \\
\hline 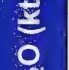 & $N$ & $\sigma$ & $N$ & $\nabla$ & N & $N$ & $\nabla$ & 10 & $\bar{m}$ & - & $N$ & $\stackrel{L}{R}$ & $\sigma$ & $\nabla$ & $\widehat{m}$ & 0 \\
\hline & 0 & 0 & $\stackrel{m}{\square}$ & లి & 尔 & $\stackrel{\infty}{\sim}$ & $\mp$ & 0 & $r$ & 0 & () & $N$ & - & $r$ & $\sim$ & 0 \\
\hline กี & $\frac{10}{\sigma}$ & $\begin{array}{l}\text { J্ } \\
\text { m్ } \\
-\end{array}$ & జ్ & ల్గి & $\begin{array}{l}\text { 옹 } \\
\infty \\
-\end{array}$ & ని & స్లి & $\frac{+}{\sigma}$ & 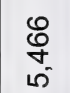 & $\stackrel{\infty}{\leftarrow}$ & $\stackrel{ \pm}{\sim}$ & 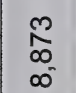 & $\stackrel{?}{\circ}$ & 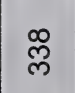 & 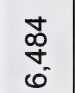 & $\stackrel{2}{\sim}$ \\
\hline 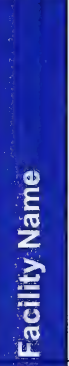 & 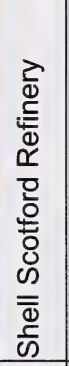 & 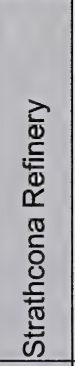 & 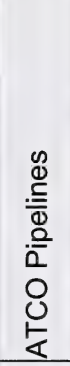 & 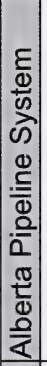 & 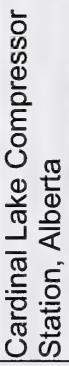 & 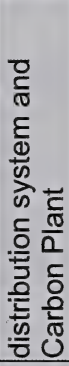 & 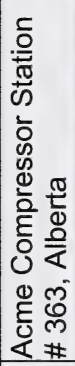 & 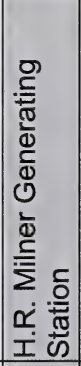 & 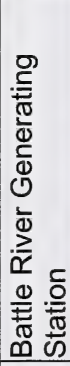 & 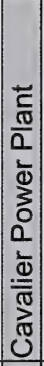 & 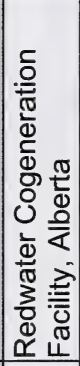 & 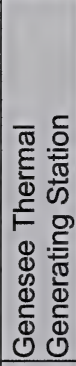 & 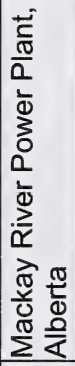 & 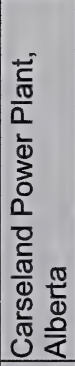 & 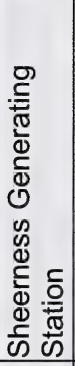 & 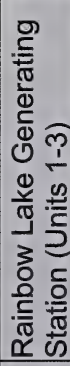 \\
\hline$\frac{5}{8}$ & 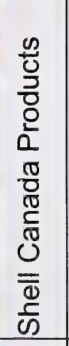 & 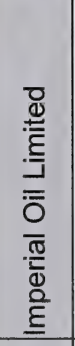 & 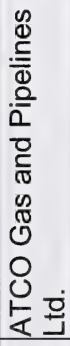 & 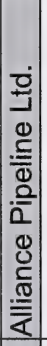 & 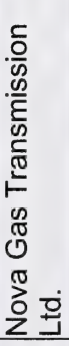 & 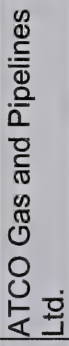 & 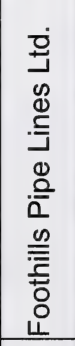 & 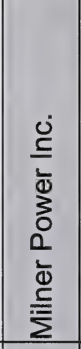 & 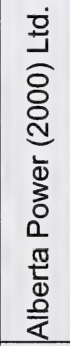 & 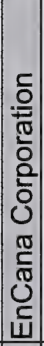 & 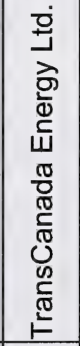 & 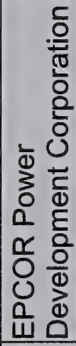 & 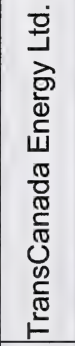 & 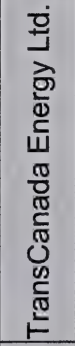 & 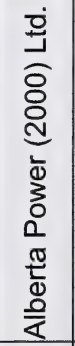 & 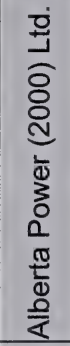 \\
\hline$\frac{3}{\frac{3}{6}}$ & 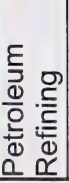 & 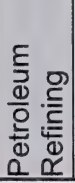 & 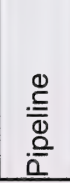 & 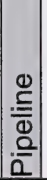 & 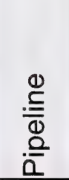 & 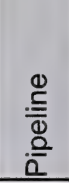 & 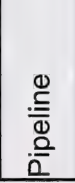 & $\begin{array}{l}\frac{c}{\pi} \\
\frac{\pi}{\alpha} \\
\frac{1}{0} \\
0 \\
0 \\
0\end{array}$ & 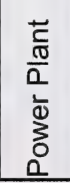 & \begin{tabular}{|c|}
$\frac{c}{0}$ \\
$\frac{\pi}{\alpha}$ \\
$\frac{1}{0}$ \\
3 \\
0 \\
0 \\
0
\end{tabular} & $\begin{array}{l}\frac{\overrightarrow{0}}{\sigma} \\
\frac{\pi}{\alpha} \\
\bar{\phi} \\
0 \\
0 \\
0\end{array}$ & $\begin{array}{l}\overrightarrow{\tilde{\sigma}} \\
\frac{\pi}{\alpha} \\
\bar{\phi} \\
\bar{\alpha} \\
0 \\
0\end{array}$ & 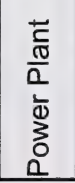 & 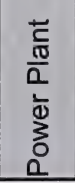 & 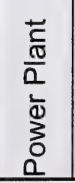 & 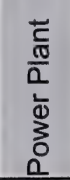 \\
\hline
\end{tabular}




\begin{tabular}{|c|c|c|c|c|c|c|c|c|c|c|c|c|}
\hline $\begin{array}{l}\frac{\mathrm{U}}{\mathrm{T}} \\
\frac{\mathrm{U}}{\mathrm{N}} \\
\frac{\mathrm{N}}{\mathrm{E}}\end{array}$ & $\bar{\aleph}$ & 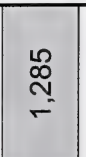 & $\stackrel{?}{\sim}$ & $\stackrel{\widehat{\infty}}{\stackrel{\infty}{+}}$ & $\stackrel{m}{=}$ & స్ & $\frac{\infty}{\infty}$ & $\frac{\bar{\infty}}{\check{\sigma}}$ & $\frac{\frac{J}{6}}{6}$ & - & مـ & $\stackrel{\infty}{\leftarrow}$ \\
\hline & & & & & & & & & & & & \\
\hline 0 & $N$ & $\Lambda$ & $N$ & 0 & $r$ & $m$ & $\stackrel{\varphi}{\circ}$ & $\stackrel{ }{\rightleftharpoons}$ & ร & 0 & 0 & 0 \\
\hline 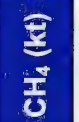 & 0 & - & $\nabla$ & $r$ & 0 & - & $r$ & $\sigma$ & - & 0 & 0 & 0 \\
\hline ô & 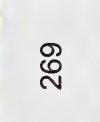 & $\underset{\mathrm{N}}{\stackrel{N}{=}}$ & ల్లి & 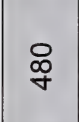 & 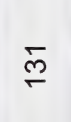 & প్ల & $\begin{array}{l}\frac{\&}{\sim} \\
\stackrel{i}{2}\end{array}$ & 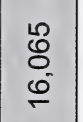 & $\frac{\overline{0}}{6}$ & - & ما & $\stackrel{\infty}{\sim}$ \\
\hline$\frac{\stackrel{\omega}{c}}{\frac{\pi}{2}}$ & 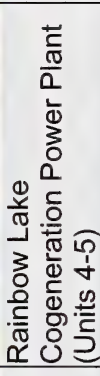 & 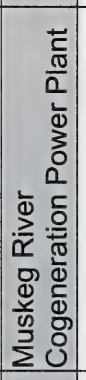 & 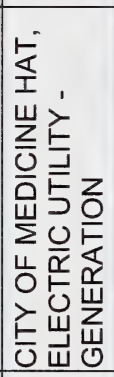 & 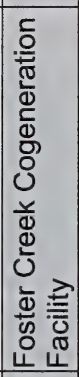 & 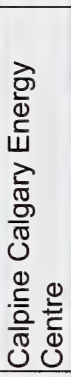 & 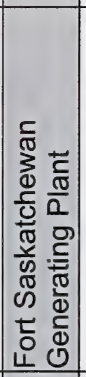 & 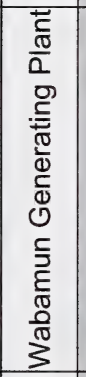 & 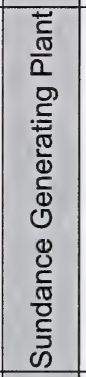 & 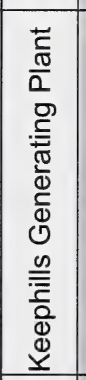 & 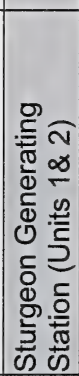 & 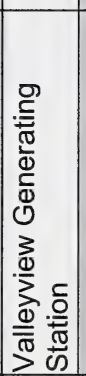 & 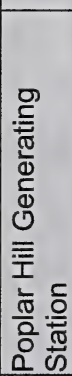 \\
\hline 8 & 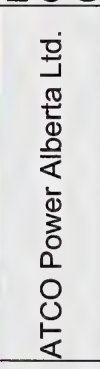 & 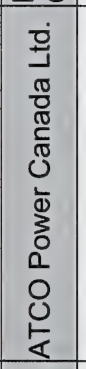 & 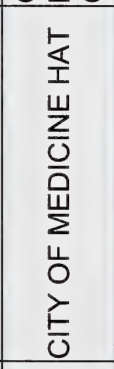 & 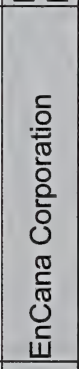 & 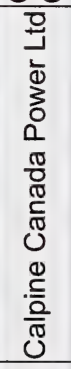 & 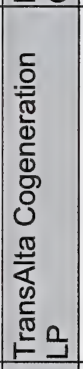 & 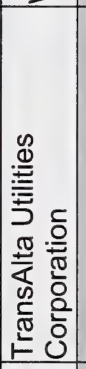 & 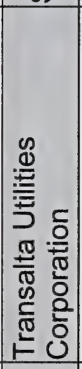 & 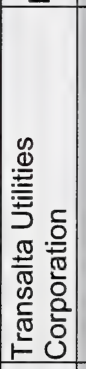 & 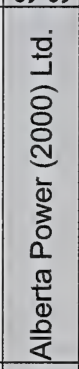 & 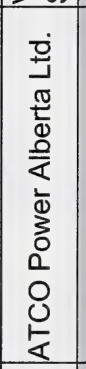 & 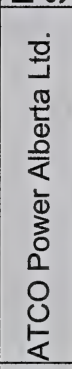 \\
\hline 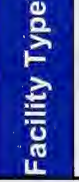 & 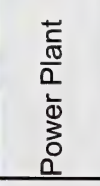 & 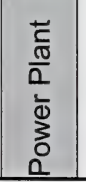 & 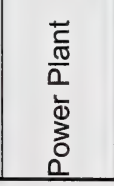 & 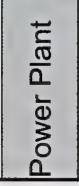 & 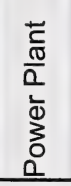 & 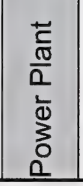 & 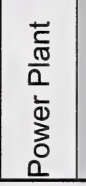 & $\begin{array}{l}\overline{\tilde{T}} \\
\frac{\pi}{0} \\
\overline{0} \\
\overline{0} \\
\overline{0} \\
\Omega \\
0\end{array}$ & 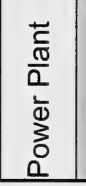 & $\begin{array}{l}\overrightarrow{\tilde{c}} \\
\frac{\pi}{0} \\
\underline{0} \\
\overline{0} \\
0 \\
0\end{array}$ & 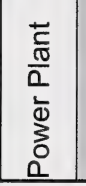 & 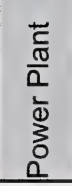 \\
\hline
\end{tabular}




\section{References:}

${ }^{\mathrm{i}}$ Albertans and Climate Change: Taking Action. Alberta Environment, Government of Alberta. October, 2002. http://www3.gov.ab.ca/env/climate/docs/takingaction.pdf.

ii Alberta Specified Gas Reporting Program. Alberta Environment, Government of Alberta. May 2006. http://www3.gov.ab.ca/env/air/EMR/sgreporting.html.

iii Specified Gas Reporting Standard. Alberta Environment, Government of Alberta. March 2006.

http://www3.gov.ab.ca/env/air/pubs/ghg_specified_gas_reporting_standard.pdf.

iv Specified Gas Reporting Regulation, Alberta Regulation 251/2004, Alberta Environment, Government of Alberta. http://www.qp.gov.ab.ca/documents/Regs/2004_251.cfm?frm_isbn=0779733134.

${ }^{v}$ Climate Change and Emissions Management Act. Alberta Environment, Government of Alberta. February 2005. http://www.qp.gov.ab.ca/documents/Acts/C16P7.cfm?frm isbn=0779733363.

vi National Inventory Report, 1990-2004 - Greenhouse Gas Sources and Sinks in Canada. Environment Canada, Government of Canada. April 2006. http://www.ec.gc.ca/pdb/ghg/inventory report/2004_report/toc_e.cfm .

${ }^{v i i}$ United Nations Framework Convention on Climate Change. United Nations. June 1992. http://unfccc.int/not assigned/b/items/1417.php.

viii Revised 1996 IPCC Guidelines for National Greenhouse Gas Inventories. Intergovernmental Panel on Climate Change (IPCC)/Organization for Economic Cooperation and Development (OECD)/International Energy Agency (IEA), 1997. http://www.ipcc-nggip.iges.or.jp/public/gl/invs1.htm.

${ }^{\text {ix }}$ State of the Environment - Climate Change. Alberta Environment, Government of Alberta. December 2006.

http://www3.gov.ab.ca/env/soe/climate indicators/15 ghg.html.

\section{Other References:}

Climate Change 2001: The Scientific Basis. Intergovernmental Panel on Climate Change. 2001. http://www.grida.no/climate/ipcc tar/wgl/index.htm

Climate Change - Greenhouse Gas Emissions. United States Environmental Protection Agency. October 2006. http://www.epa.gov/climatechange/emissions/index.html.

Climate Change Science: An Analysis of Some Key Questions. National Research Council (United States). 2001. http://newton.nap.edu/html/climatechange/. 


\section{Data Sources:}

2004 National Greenhouse Gas Inventory Data. Environment Canada, Government of Canada. April 2006.

http://www.ec.gc.ca/pdb/ghg/inventory_report/2004_report/toc e.cfm.

2005 Alberta GHG Data. Alberta Environment, Government of Alberta. Nov 30, 2006.

2005 National Greenhouse Data. Environment Canada, Government of Canada. Dec 20, 2006. http://www.ec.gc.ca/pdb/ghg/onlineData/dataSearch_e.cfm. 

